\title{
76. THE AGING OF OCEANIC CRUST: SYNTHESIS OF THE MINERALOGICAL AND CHEMICAL RESULTS OF DEEP SEA DRILLING PROJECT, LEGS 51 THROUGH 53
}

\author{
Thomas W. Donnelly, Department of Geological Sciences, \\ State University of New York at Binghamton, Binghamton, New York \\ Richard A. Pritchard, ${ }^{1}$ Department of Geology, University of Newcastle, Tyne \& Wear, England \\ and \\ R. Emmermann and H. Puchelt, Institut für Petrographie und Geochemie der Universität, \\ Karlsruhe (T.H.), Kaiserstrasse 12, D-7500 Karlsruhe, West Germany
}

\begin{abstract}
The alteration of young oceanic crust produces limited quantities of a poorly ordered smectite phase very low in Al. This phase, which is produced dominantly by the early breakdown of the least stable minerals (especially olivine), spans a compositional range from celadonite to saponite. The alteration minerals of older crust cluster at the end members of this range and produce either a celadonite or saponite X-ray pattern. They are more aluminous than earlier smectite, reflecting the alteration of both glass and fine-grained groundmass. The very highly altered Hole 417A basalts have an abundance of high-Al clay minerals, consistent with the nearly complete breakdown of the original glass and minerals of the basalt. Thus, the variations of mineralogy reflect both the extent of breakdown of the original materials and the aging of these minerals.

Older crust is more $\mathrm{H}_{2} \mathrm{O}$-rich and $\mathrm{CO}_{2}$-rich, but is not convincingly more oxidized nor K-rich than younger crust. The chemical expression of aging is the reaction of basalt with water trapped in fractures, but there is little oxidative capacity of this water and it cannot exchange readily with sea water. Certain minor elements are enriched in the crust $(\mathrm{B}, \mathrm{Li}, \mathrm{Rb}$, $\mathrm{Cs}$, and $\mathrm{Ba}$ ). Of these, $\mathrm{Rb}$ appears to be enriched in altered basalts about eight times its sea water value, relative to $\mathrm{K}$, possibly indicating a mineralogical preference for this element. Cs and Ba would appear to be even more highly enriched, relative to $\mathrm{K}$, but the data for these elements are less convincing.
\end{abstract}

\section{INTRODUCTION}

One of the principal aims of drilling during Legs 51 and 52 (subsequently extended to Leg 53 ) was the study of old oceanic crust. Previous deep penetrations (Legs 37, 45, and 46) had been in crust up to $13 \mathrm{~m} . \mathrm{y}$. old; the crust penetrated on Leg 51 through 53 is $110 \mathrm{~m} . \mathrm{y}$. old. The isotopic, physi$\mathrm{cal}$, and magnetic properties of this old crust are described elsewhere in this volume; in this chapter, we intend to review its chemical and mineralogical character. The following questions have to be dealt with: (1) What are the mineralogical changes which the crust has undergone through aging?, and (2) What are the chemical exchanges that have taken place during the period concerned? From the answers to these questions we hope to determine the temperature history of the crust, the relationship between crustal mineralogy and physical properties, and the extent of crustal involvement in the cycles of chemical elements in sea water.

\footnotetext{
'Present address: Ruhr-Universität Bochum, Institut für Mineralogie, Bochum, West Germany.
}

The specimens discussed in this paper are from Legs 51 through 53 and from Leg 37; other penetrations of crust have provided few comparative data and are mentioned only incidentally. Of principal interest are Holes 332A, 332B, and 335 from Leg 37 (Aumento, Melson, et al., 1977) and Holes 417D and 418A from Legs 51 through 53. According to the shipboard party on Leg 37 , Hole $332 \mathrm{~A}$ has provided the freshest example of crust, whereas the basalt from Hole 332B is apparently more altered; both are about $3.5 \mathrm{~m} . \mathrm{y}$. old. Hole 335 (about 13 m.y.) is represented by fewer samples. Holes 417D and 418A (110 m.y.) represent relatively fresh, old crust. Hole 417A represents old crust which was extensively altered shortly after its formation.

\section{MINERALOGY}

\section{Introduction}

Mineralogical studies of samples from Legs 51 through 53 are of three main types: X-ray diffraction, petrography, and chemical analysis by means of the electron microprobe. We have compared these results with those obtained by Robinson et al., 1977; Andrews et al., 1977; and Baragar et al. 1977 (Sites 332 and 335, Leg 37) - all of whom report 
probe data on compositions - and, to a lesser extent, with data by Bass (1976) and Seyfried et al. (1976), who provide petrographic and limited chemical information on Leg 34 samples. There are several problems involved in constructing a coherent mineralogical synthesis from these diverse forms of data. The samples represent rocks of widely differing ages, and the mineralogies can be expected to differ. Also, the samples studied by X-ray analysis (e.g., Schiedegger and Stakes, this volume) were only rarely matched to probed samples; generally, the latter were not $\mathrm{X}$-rayed, and vice versa. The microprobe does not differentiate between ferric and ferrous iron; and assignment of oxidation states to the various minerals is difficult. Many probed minerals cannot be recast into simple mineral formulae, and these probably represent composite grains. Nevertheless, it is possible to discuss the data in terms of hypothetical mineral end members and to relate the observed mineral assemblages to the age and conditions of crust formation.

\section{Format}

In the following section, the data are summarized and discussed in terms of three idealized mineral groups of samples, respectively, from: (1) Sites 332 and 335; (2) Holes 417D and 418A; and (3) Hole 417A. The first group represents young, relatively unaltered basalt; the second represents old, nearly unaltered basalt; and the third represents old basalt which was evidently pervasively altered at a very young age (Donnelly et al., this volume; Hart and Staudigel, this volume). The diagrams accompanying this section are of two types: a triangular diagram relating relative weight percentages of $\mathrm{Al}_{2} \mathrm{O}_{3}, \mathrm{FeO}^{*}$, and $\mathrm{MgO}$ (Figures $1,3,5$, and 7) and an orthogonal plot relating the atomic ratios $\mathrm{K} / \mathrm{Si}$ and $(\mathrm{Fe}+\mathrm{Mg}) / \mathrm{Si}$ (Figures 2, 4, 6, and 8). Summary diagrams for the three groups are shown as Figures 1 and 2, and diagrams showing probe analyses (from Rusinov et al., this volume; Pritchard, this volume; Mevel, this volume; Juteau et al., this volume; and Humphris et al., this volume; as well as additional unpublished data of Pritchard for Hole 417A) in the same format and using the same symbology are presented in Figures 3 through 8 .

\section{Celadonite}

This mineral is widespread, conspicuous, and fairly constant in composition at the older sites. The average composition (Table 1) is of a dioctahedral mica with about threequarter occupancy of the interlayer sites by $\mathrm{K}$, a low $\mathrm{Al}$ content ( $\mathrm{Si} / \mathrm{Al}$ ratio about $11 / 1)$ in the tetrahedral layer, with the Fe evidently in the ferric state, and an $\mathrm{Fe} / \mathrm{Mg}$ ratio of about $3 / 1$. A subgroup of young samples which occur as a continuous series with micaceous and saponitic end members is shown in Figures 3 and 4 . These younger samples generally have only about a third as much $\mathrm{Al}$ in the tetrahedralites as do the older, but the remainder of the composition is very similar. A strong justification for recasting the $\mathrm{Fe}$ in the ferric form is seen in the octahedral layer occupancy calculations. With ferric iron, the octahedral layer occupancies are very nearly 4.0 , but reducing some or all of the Fe makes these depart from this value. An analogous case of green sedimentary micas was found for Leg 54 samples (Donnelly, in press), whose brilliant green coloration was

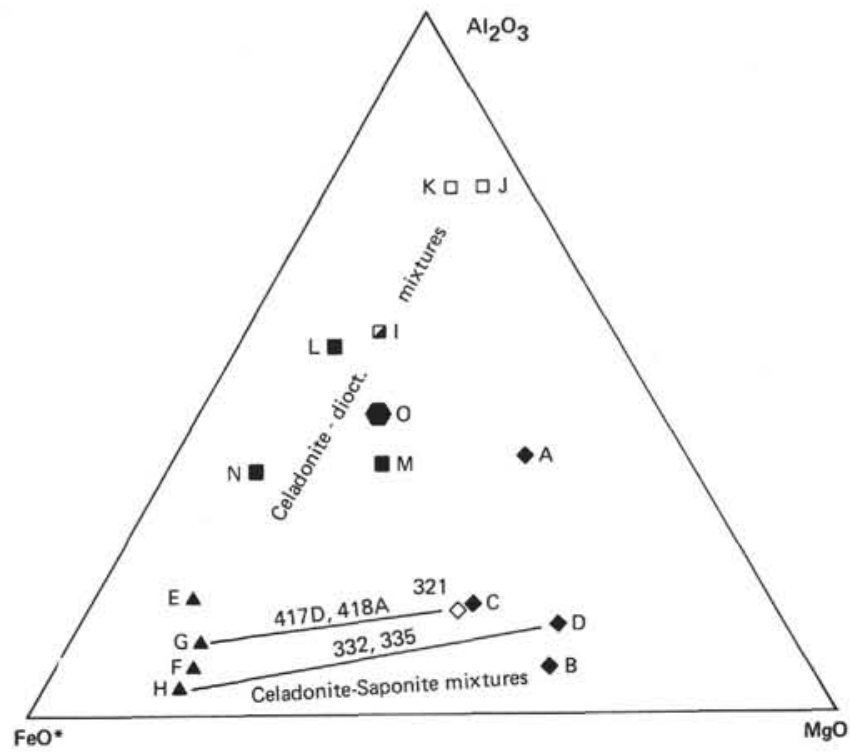

Figure 1. Triangular diagram relating $\mathrm{Al}_{2} \mathrm{O}_{3}, \mathrm{FeO}$, and $\mathrm{MgO}$ (weight) for clay minerals, palagonite and glass from Sites 332, 335, 417 and 418, as averaged in Table 1. The solid hexagon $(O)$ is the average glass composition in Hole 417D (Byerly and Sinton, this volume). The solid squares are palagonite averages for Sites 332 and $335(N), 417 A(L)$ and $417 D$ and $418 A(M)$. The solid diamonds are saponites for Hole $417 A$ ( $A$, high $A l ; B$, low Al), Holes 417D and 418A (C) and Sites 332 and 335 (D). The open diamond is the average smectite composition at Site 321 (Bass, 1976; Seyfried et al., 1976). The open squares are $A l=$ rich clays from feldspar crystals at Site 417A ( $K$ from Pritchard, $J$ are pinkish clays from Mevel). The half-filled square (I) is the average dioctahedral clay mixture in Hole $417 A$. The solid triangles are average celadonites for Hole $417 \mathrm{~A}$ (E, high $A l ; F$, low Al), Holes $417 D$ and $418 A(G)$, and Sites 332 and $335(\mathrm{H})$.

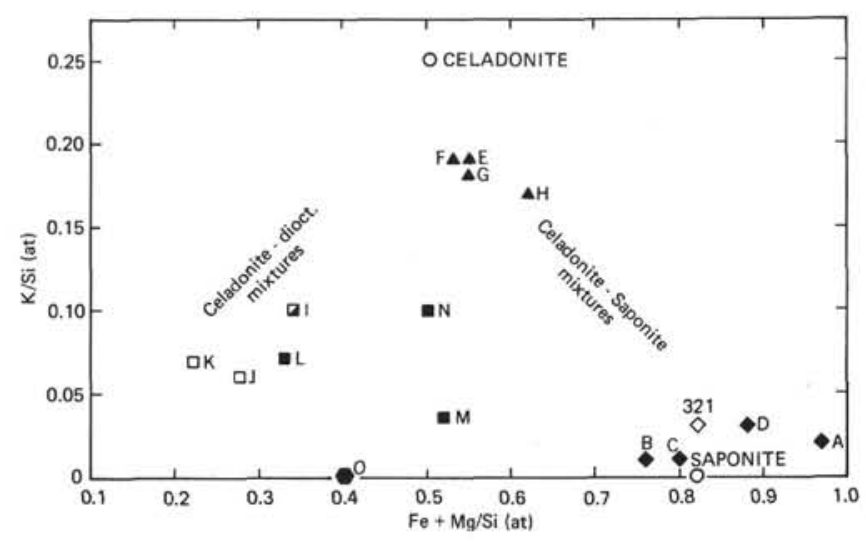

Figure 2. Diagram relating the atomic ratios $K / S i$ versus $(\mathrm{Fe}+\mathrm{Mg}) / \mathrm{Si}$ for averages of clay/minerals, palagonite, and glass from Sites 332, 335, 417, and 418, as in Figure 1. In addition to symbols explained in Figure 1, the open circles show idealized celadonite and saponite compositions. 


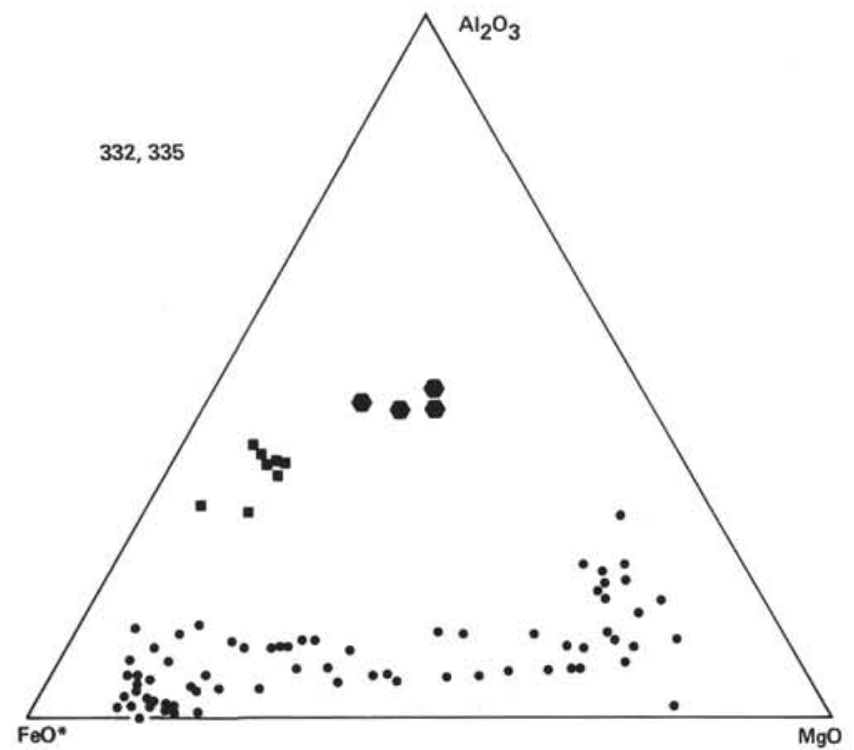

Figure 3. Triangular diagram $\mathrm{Al}_{2} \mathrm{O}_{3}-\mathrm{FeO}^{*}-\mathrm{MgO}$, as in Figure 1, for all data from Sites 332 and 335 (data from Robinson et al., 1977; Andrews et al., 1977; and Baragar et al., 1977). Hexagons are glass compositions, and solid squares are palagonites. All smectites are shown as solid circles.

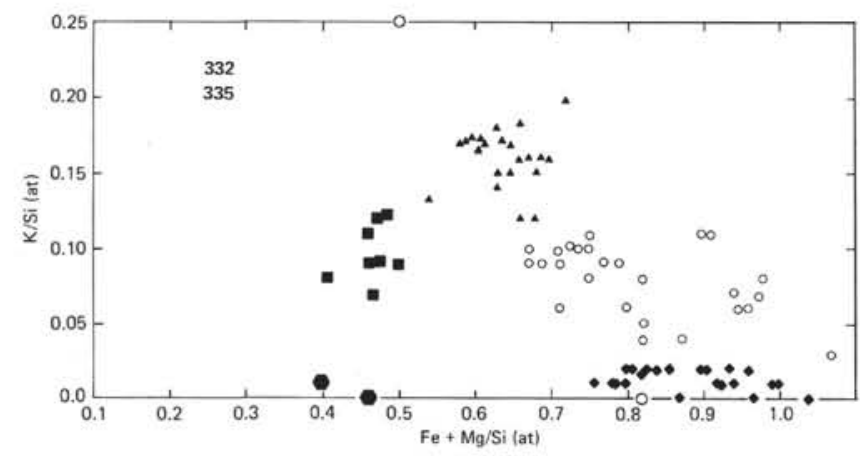

Figure 4. Diagram relating $\mathrm{K} / \mathrm{Si}$ versus $(\mathrm{Fe}+\mathrm{Mg}) / \mathrm{Si}$, as in Figure 2, for Sites 332 and 335. Solid circles of Figure 3 replaced by arbitrarily chosen groupings displaying celadonite-like, saponite-like, and intermediate compositions. The solid triangles represent group $H$ of Table 1 and Figures 1 and 2, the solid diamonds represent Group D. Open circles show ideal celadonite and saponite.

attributed to ferric iron by direct chemical analysis. There is a tendency among petrologists to associate green coloration with reduction, but many minerals (such as aegirine and epidote, as well as the sedimentary mica already cited) owe their intense green to ferric iron. Evidence that there does not exist a small component of mixed-layer trioctahedral smectite - raising the octahedral occupancy above 4.0 and allowing considerable $\mathrm{Fe}$ to exist in the ferrous state - is negative or circumstantial, and this assignment should probably be investigated by Mossbauer spectroscopy. The negative evidence is the absence of the trioctahedral peak; and the circumstantial evidence is both the coincidence of

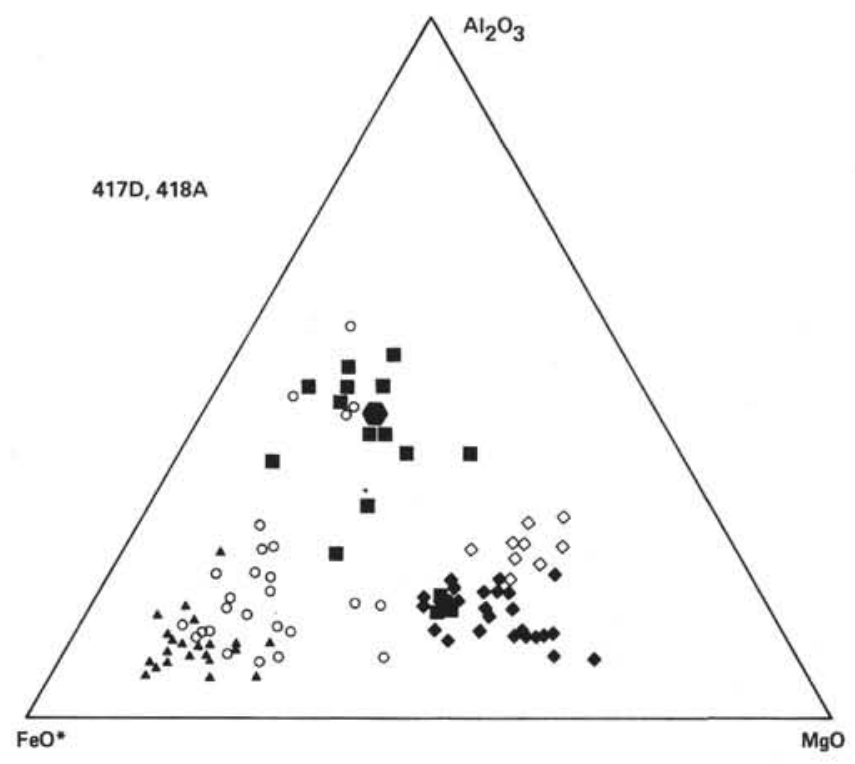

Figure 5. Triangular diagram $\mathrm{Al}_{2} \mathrm{O}_{3}-\mathrm{FeO}{ }^{*}-\mathrm{MgO}$, as in Figure 1 , for all data from Holes $417 D$ and $418 A$. Hexagon represents average Hole $417 D$ glass, solid squares are palagonites (Group $M$ of Table 1), solid triangles are celadonites, solid diamonds are saponites (Group C), open diamonds are chlorites, and open circles represent intermediate and unaveraged compositions.

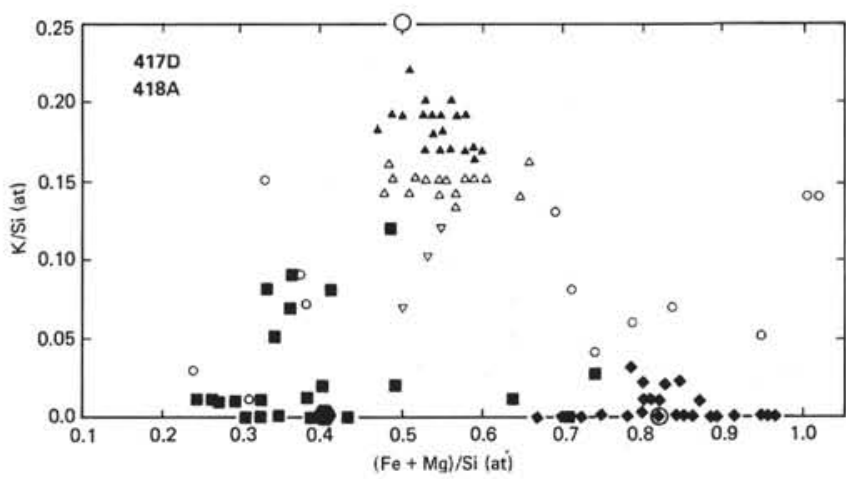

Figure 6. Diagram relating $\mathrm{K} / \mathrm{Si}$ versus $(\mathrm{Fe}+\mathrm{Mg}) / \mathrm{Si}$ for Holes $417 D$ and 418A. Symbols as in Figure 5, except that open upright and inverted triangles are used here for celadonite-like phases deficient in $K$. Solid triangles represent Group $G$ of Table 1. Remaining unaveraged samples are represented by small open circles.

the 4.0 octahedral occupancy when calculated as ferric and the abundance of these micas in rocks which are themselves nearly completely oxidized at Hole 417A.

The younger samples (Sites 332 and 335 ) yielded no mica $\mathrm{X}$-ray patterns; chemical analogy strongly suggests, however, that their clay minerals tend in one compositional extreme toward the same celadonite. In the absence of $\mathrm{X}$-ray confirmation, we introduce the term "protoceladonite,"' which may be defined as a clay mineral whose chemical properties group it with the micas but that has no mica recognizable by $\mathrm{X}$-ray pattern. We conjecture that the transition from protoceladonite to celadonite results from aging 


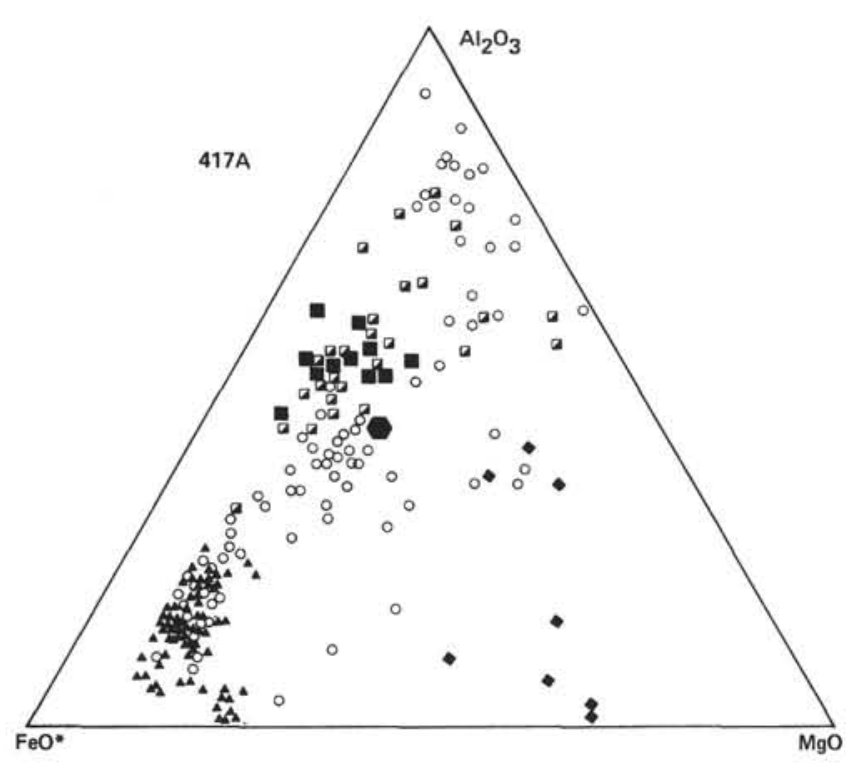

Figure 7. Triangular diagram $\mathrm{Al}_{2} \mathrm{O}_{3}-\mathrm{FeO}{ }^{*}-\mathrm{MgO}$ for all the data from Hole 417A. Symbols similar to those in Figures 1 and 2, with the hexagon representing the average glass composition in Hole $417 D$, the solid squares representing palagonite (Group L), the solid diamonds saponites (Groups $A$ and $B$ ), the solid triangles celadonites, and the half-filled squares representing mixtures of dioc tahedral phases (Group I). Remaining unaveraged minerals, and high-Al clays from feldspars, shown as open circles.

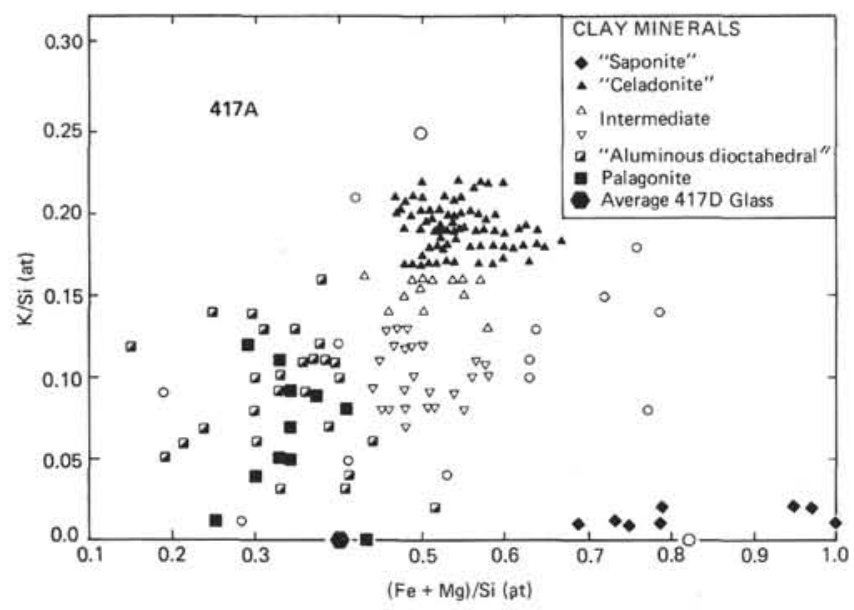

Figure 8. Diagram relating $\mathrm{K} / \mathrm{Si}$ versus $(\mathrm{Fe}+\mathrm{Mg}) / \mathrm{Si}$ for Hole 417A. Symbols as in Figure 7, except that celadonites of groups $E$ and $F$ are solid triangles, and open upright and inverted triangles are K-deficient celadonitelike phases not averaged in Table 1.

and crystal ordering. Thus, protoceladonite in Sites 332 and 335 is a compositional end member of a mixed-layer series whose other end member is saponite (see section following).

Figures 5 through 9 show compositions of clay minerals for basalts from Legs 51 through 53. Note that in two cases - Holes 417D and 418A; and Hole 417A - there are relatively few samples with compositions intermediate be- tween the celadonite and saponite end members. Furthermore, the average $\mathrm{Al}$ contents are higher in the older specimens, where it was also found that the $\mathrm{K}$ content of the celadonite increases by only a very small amount.

The behavior of $\mathrm{Al}$ in the formation of the mica minerals is shown in Figures 9 and 10 , which relate the $(\mathrm{Fe}+\mathrm{Mg}) / \mathrm{Al}$ ratio to the $\mathrm{Si} / \mathrm{Al}$ ratios for clay minerals. The symbols used show that the more potassic celadonites are the least aluminous. In Holes 417D and 418A (Figure 9), very few clay minerals are as aluminous as the basalt glass. In Hole $417 \mathrm{~A}$, there is a cluster of clays more aluminous than the glass. In the latter case, this evidently represents a complete breakdown of the glass into a more and a less aluminous clay mineral suite. The high degree of correlation of these variables emphasizes the rather unimportant role of $\mathrm{Al}$ in the formation of these minerals; in both the celadonitic and saponitic end members, an Al-free end member is approached.

Also related to $\mathrm{Al}$ is the $\mathrm{Fe} / \mathrm{Mg}$ ratio of the clays (Figure 11). The most aluminous clays of Hole $417 \mathrm{~A}$ tend to have a wide range of $\mathrm{Fe} / \mathrm{Mg}$ ratios [plotted here as $\mathrm{Fe} /(\mathrm{Fe}+\mathrm{Mg})]$, with a very slight tendency for the more aluminous minerals to be most magnesian. For celadonite with an $\mathrm{Si} / \mathrm{Al}$ ratio greater than 5 (that of the original basalt is about 3 ), the $\mathrm{Fe}$ value $[\mathrm{Fe} /(\mathrm{Fe}+\mathrm{Mg})]$ is fairly constant at about $0.75 . \mathrm{Fe} /$ $(\mathrm{Fe}+\mathrm{Mg})$ values for samples with $\mathrm{Si} / \mathrm{Al}$ greater than 7 are not shown, but have very similar ratios. This relationship clarifies the compositions of end member celadonite in these rocks and emphasizes its identity as a mineral species.

\section{Saponite}

The second clay mineral species is a trioctahedral smectite, on the basis of evidence both by X-ray analysis (Scheidegger and Stakes, this volume) and octahedral layer occupancy (Table 1). This mineral is dominantly magnesian ( $\mathrm{Fe} / \mathrm{Mg}$ ratio about $1 / 3.5$ ), and in most cases highly siliceous (tetrahedral $\mathrm{Si} / \mathrm{Al}$ ratio about 10/1). The calculated exchange ions are dominantly $\mathrm{Ca}$ (disregarding $\mathrm{Mg}$ entirely). The octahedral site occupancies are close to 6.0 when the $\mathrm{Fe}$ is calculated as ferrous, except in young samples (Sites 332, 335), for which, in an occupancy of close to 6.0 , a 50:50 ferric/ferrous ratio results. As was the case for celadonite, this ratio is not known directly, but the conjecture is that the $\mathrm{Fe}$ is dominantly ferrous in this mineral. This is also consistent with its scarcity in the highly oxidized part of Hole 417A and its greater abundance in rocks for which the bulk ferric/ferrous ratio is low.

\section{Celadonite - Saponite Mixtures}

The minerals of the younger samples (Sites 332 and 335) form a compositional continuum (Figures 3 and 4). The only X-ray patterns obtained from these minerals were of smectite, and this evidently displays a compositionally continuous variation between the end members expressed as a mixed-layer smectite-mica. In older samples (Figures 5 through 8), similar gradational tendencies are more restricted, and it cannot be demonstrated that these minerals are mixed-layer single crystals.

\section{Dioctahedral Montmorillonite - Celadonite Mixtures}

In Hole 417A, abundant clay minerals occur, especially in the shallower, more completely altered samples that 
TABLE 1

Compositions and Computed Cell Formulae for Averaged Groupings of Clay Minerals, Palagonites, and Glass - Sites 332, 335, 417, and 418

\begin{tabular}{|c|c|c|c|c|c|c|c|c|c|c|c|c|c|c|c|}
\hline \multirow{2}{*}{$\begin{array}{l}\text { Mineral } \\
\text { Group }\end{array}$} & \multicolumn{4}{|c|}{ Saponite } & \multicolumn{4}{|c|}{ Celadonite } & \multirow{2}{*}{$\begin{array}{c}\text { Dioctahedral } \\
\text { Mixtures } \\
\text { I }\end{array}$} & \multicolumn{2}{|c|}{$\begin{array}{c}\text { Al-Rich Clays } \\
\text { Feldspar }\end{array}$} & \multicolumn{3}{|c|}{ Palagonite } & \multirow{2}{*}{$\begin{array}{c}\text { Glass } \\
0\end{array}$} \\
\hline & A & B & C & D & E & $\mathrm{F}$ & G & $\mathrm{H}$ & & $\mathbf{J}$ & K & L & M & $\mathrm{N}$ & \\
\hline Site/Hole & $417 \mathrm{~A}$ & $417 \mathrm{~A}$ & $\begin{array}{l}417 \mathrm{D} \\
418 \mathrm{~A}\end{array}$ & $\begin{array}{l}332 \\
335 \\
\end{array}$ & $417 \mathrm{~A}$ & $417 \mathrm{~A}$ & $\begin{array}{l}417 \mathrm{D} \\
418 \mathrm{~A}\end{array}$ & $\begin{array}{l}332 \\
335\end{array}$ & $417 \mathrm{~A}$ & $417 \mathrm{~A}$ & $417 \mathrm{~A}$ & $417 \mathrm{~A}$ & $\begin{array}{l}417 \mathrm{D} \\
418 \mathrm{~A} \\
\end{array}$ & $\begin{array}{l}332 \\
335\end{array}$ & 417D \\
\hline $\mathrm{SiO}_{2}$ & 38.7 & 52.4 & 47.1 & 46.1 & 47.5 & 51.9 & 50.2 & 49.9 & 48.7 & 46.7 & 46.5 & 44.0 & 49.0 & 41.6 & 50.7 \\
\hline $\mathrm{TiO}_{2}$ & 0 & 0.06 & $-\mathrm{a}$ & -a & 0.02 & 0.01 & 0.07 & 0.01 & 0.24 & $-\mathrm{a}$ & 0 & $-^{a}$ & 1.52 & $-\mathrm{a}$ & 1.60 \\
\hline $\mathrm{Al}_{2} \mathrm{O}_{3}$ & 17.1 & 2.54 & 5.40 & 4.67 & 5.78 & 2.27 & 3.56 & 1.36 & 18.7 & 29.5 & 25.3 & 16.4 & 12.9 & 11.6 & 14.3 \\
\hline $\mathrm{FeO}^{*}$ & 9.23 & 10.9 & 12.4 & 10.2 & 24.0 & 23.6 & 23.8 & 27.0 & 9.83 & 2.06 & 3.06 & 10.8 & 13.3 & 17.9 & 11.5 \\
\hline $\mathrm{MgO}$ & 20.0 & 20.7 & 18.2 & 21.4 & 4.19 & 5.08 & 5.16 & 5.61 & 5.66 & 7.40 & 5.13 & 3.90 & 9.48 & 3.89 & 7.2 \\
\hline $\mathrm{CaO}$ & 0.88 & 1.23 & 1.56 & 0.70 & 0.70 & 0.51 & 0.69 & 0.27 & 1.82 & 1.59 & 1.77 & 4.25 & 2.34 & 1.13 & 11.8 \\
\hline $\mathrm{Na}_{2} \mathrm{O}$ & 0 & 0.26 & 0.34 & 0.70 & 0.03 & 0.03 & 0.03 & 0.30 & 0.29 & 0.06 & 0.70 & 1.06 & 0.14 & 0.89 & 2.3 \\
\hline $\mathrm{K}_{2} \mathrm{O}$ & 0.56 & 0.31 & 0.29 & 0.95 & 7.00 & 7.86 & 7.21 & 6.59 & 3.71 & 0.91 & 2.40 & 2.46 & 1.01 & 3.13 & 0.1 \\
\hline Number & 43 & 4 & 18 & 26 & 52 & 27 & 20 & 10 & 23 & 5 & 9 & 11 & 16 & 8 & 98 \\
\hline \multicolumn{16}{|l|}{ Tetrahedral } \\
\hline $\mathrm{Si}$ & 5.66 & 7.63 & 7.22 & 6.99 & 7.12 & 7.58 & 7.38 & 7.36 & 6.88 & 6.36 & 6.83 & 6.96 & 7.04 & 6.79 & 7.24 \\
\hline $\mathrm{Al}$, & 2.34 & 0.37 & 0.88 & 0.83 & 0.88 & 0.39 & 0.62 & 0.24 & 1.12 & 1.64 & 1.17 & 1.04 & 0.96 & 1.21 & 0.76 \\
\hline $\mathrm{Fe}^{3+}$ & - & - & - & 0.18 & - & 0.03 & - & 0.40 & - & & & - & - & - & - \\
\hline \multicolumn{16}{|l|}{ Octahedral } \\
\hline $\mathrm{Al}$ & 0.61 & 0.07 & 0.10 & & 0.14 & - & - & - & 1.99 & 3.10 & 2.95 & 2.03 & 1.22 & 1.02 & 1.65 \\
\hline $\mathrm{Fe}^{3+}$ & 1.13 & - & - & 0.47 & 3.01 & 2.85 & 2.93 & 2.93 & 1.16 & 0.23 & 0.35 & 1.43 & 1.66 & 2.44 & 1.37 \\
\hline $\mathrm{Fe}^{2+}$ & - & 1.33 & 1.59 & 0.65 & - & - & - & - & - & - & - & - & - & - & - \\
\hline $\mathrm{Mg}$ & 4.36 & 4.49 & 4.16 & 4.85 & 0.94 & 1.11 & 1.13 & 1.23 & 1.19 & 1.50 & 1.06 & 0.92 & 2.03 & 0.95 & 1.53 \\
\hline Sum & 6.10 & 5.89 & 5.85 & 5.97 & 3.95 & 3.96 & 4.06 & 4.16 & 4.34 & 4.83 & 4.36 & 4.38 & 4.91 & 4.41 & 4.55 \\
\hline \multicolumn{16}{|l|}{ Interlayer } \\
\hline $\mathrm{Ca}$ & 0.14 & 0.19 & 0.26 & 0.11 & 0.11 & 0.08 & 0.11 & 0.04 & 0.28 & 0.23 & 0.26 & $-^{\mathrm{b}}$ & $-\mathrm{b}$ & - b & $-b$ \\
\hline $\mathrm{Na}$ & 0 & 0.07 & 0.10 & 0.21 & 0 & 0.01 & 0.01 & 0.09 & 0.08 & 0.02 & 0.19 & 0.33 & 0.04 & 0.28 & 0.64 \\
\hline K & 0.10 & 0.06 & 0.06 & 0.18 & 1.34 & 1.47 & 1.35 & 1.24 & 0.67 & 0.16 & 0.42 & 0.50 & 0.19 & 0.65 & 0.02 \\
\hline
\end{tabular}

Note: Groups of minerals are selected arbitrarily as being relatively close to idealized end members, and are shown in Figures 4 through 8 . Analyses are by microprobe, with total Fe reported as $\mathrm{FeO}^{*}$. Mn values are emitted. Groups A and B are from Pritchard (unpublished); Group C, Rusinov et al.; Pritchard; and Humphris et al.; Group D, Andrews et al., 1977; and Robinson et al., 1977; and Baragar et al.; 1977; Groups E and F, mainly from Pritchard (unpublished) with additional analyses from Rusinov et al.; Mevel; Humphris et al.; Group G, from Pritchard (unpublished); Rusinov et al.; Mevel; Humphris et al.; Group H, Andrews et al., 1977; Robinson et al., 1977; Baragar et al., 1977; Group I, Pritchard (unpublished); Group J, Mevel; Group K, Pritchard (unpublished); Group L, Juteau et al.; Mevel; Group M, Rusinov et al.; Mevel; Group N, Scarfe and Smith, 1977; Baragar et al., 1977; and Group O, Byerly and Sinton. Undated references are for data appearing in this volume, except that those of Pritchard do not appear in toto. Unit cell recalculations are based on 22 oxygens, and generally assume $\mathrm{Fe}$ in the ferric state. In Groups B and C the Fe is ferrous, and in D Fe is equally divided between ferric and ferrous.

${ }_{\text {a Not determined. }}$

${ }^{b}$ Calcium in the interlayer position was not calculated for the palagonite nor for the glass.

grade in composition from celadonite toward an aluminous, dioctahedral montmorillonite end member. Unlike the celadonite-saponite series mentioned before, these minerals do not grade continuously but cluster at about two thirds smectite, one third mica, based on interlayer occupancy by $\mathrm{K}$. Both phases are considered to be dioctahedral (X-ray evidence of Juteau et al., this volume; Scheidegger and Stakes, this volume) and the octahedral occupancy of an average sample is 4.36 (Table 1). This conjectured mineral is unusual in that the octahedral occupancy is almost evenly divided among $\mathrm{Al}, \mathrm{Mg}$, and $\mathrm{Fe}$ (here considered to be ferric). The composition is close to several palagonites and may represent the initial crystallization of this phase.

\section{Clays From Feldspar Crystals, Hole 417A}

Several clays minerals which occur within feldspar crystals in Hole 417A (Mevel, this volume; Pritchard, unpublished data) are highly aluminous, slightly calcic, and have octahedral occupancies that vary between dioctahedral and trioctahedral, but which cluster closer to the former. The significance of these clays is not known, but they may represent a very special and limited environment of alteration within the calcic and aluminous phenocrysts.

\section{Palagonite}

The material identified as "palagonite" varies from site to site and in some cases from observer to observer. Many investigators restrict the term to optically isotropic, lowindex, relatively pale colored materials; others include deeply colored, isotropic materials, or slightly birefringent material ("fibropalagonite"). In the present instance the term has been applied to both isotropic material and a birefringent, fibrous material very similar to smectite.

The initial alteration of basaltic glass is hydration, generally accompanied by absorption of $\mathrm{K}$ from the water, and loss of $\mathrm{Ca}$ and, to a lesser extent, $\mathrm{Na}$. The concomitant breakdown of the least stable phenocrysts (olivine, some oxides) makes available $\mathrm{Fe}, \mathrm{Ti}, \mathrm{Si}$, and $\mathrm{Mg}$, of which all but $\mathrm{Mg}$ are absorbed in the hydrated glass. In the present examples, the younger palagonite (Sites 332 and 335) is distinctly $\mathrm{Ti}$ - and $\mathrm{Fe}$-rich, whereas older palagonite has more nearly the same $\mathrm{Fe}, \mathrm{Ti}, \mathrm{Si}$, and $\mathrm{Al}$ ratio as the original glass. Young Ti- and Fe-rich palagonite may alter through the conversion of these constituents to new minerals (oxides, micas), so that the palagonite of older samples is purged of excess quantities of these elements. Alternatively, palagonite of older rocks may include glass that formed during a 


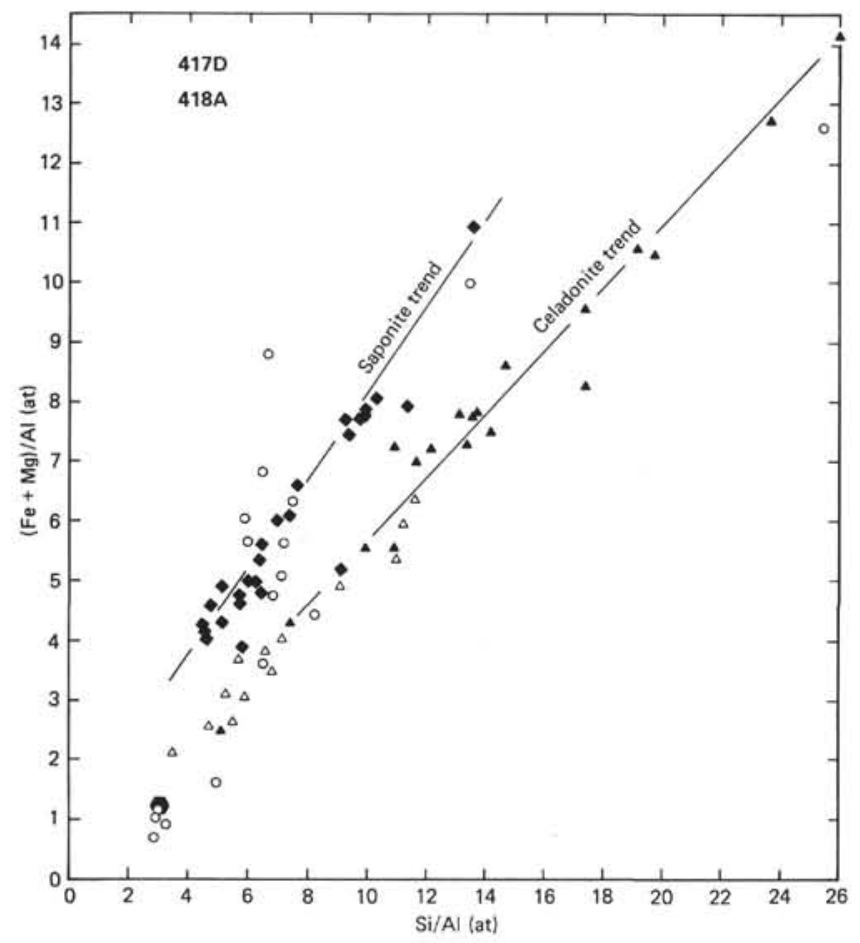

Figure 9. Diagram relating $(\mathrm{Fe}+\mathrm{Mg}) / \mathrm{Al}$ versus $\mathrm{Si} / \mathrm{Al}$ for Holes 417D and 418A. Symbols as in Figures 5 and 6. Note the celadonite and saponite trends with differing $(\mathrm{Fe}+\mathrm{Mg}) / \mathrm{Si}$ ratios, corresponding to dioctahedral and trioctahedral occupancies. Virtually all of the clays are Al poor compared to the average glass of Hole $417 D$.

more pervasive alteration of the entire rock, so that the palagonite did not receive an especially high content of some of these constituents. In the latter case, the palagonite of a more evenly altered basalt might be expected to have a composition closer to the original glass. In any event, old palagonite is closer to glass than is young palagonite.

Recasting the formula of palagonite as though it were a layered silicate mineral (Table 1) shows that this formula, disregarding $\mathrm{Ti}$ and $\mathrm{Ca}$, is remarkably like a mixture of dioctahedral and trioctahedral clay minerals, with an overall composition similar to the forementioned widespread mixed-layer dioctahedral mineral from Hole 417A. The palagonitization process appears to be an intermediate step toward the formation of clay minerals, which begins with $\mathrm{H}_{2} \mathrm{O}$ and $\mathrm{K}$ absorption and then proceeds through a stage of nucleation of a mixed-layer silicate, with the $\mathrm{K}$ and $\mathrm{Fe}$ migrating into a dioctahedral layer and the $\mathrm{Mg}$ into a trioctahedral layer or (in the presence of abundant $\mathrm{Al}$ ) into another dioctahedral layer. Further aging would result in the separation into discrete phases, which might be distributed in various ways, including the micro-banded mode resembling Liesegang rings which is characteristic of older samples.

\section{Chlorite}

Pritchard (this volume) and Mevel (this volume) have reported chlorite from Hole 418A. The occurrence is
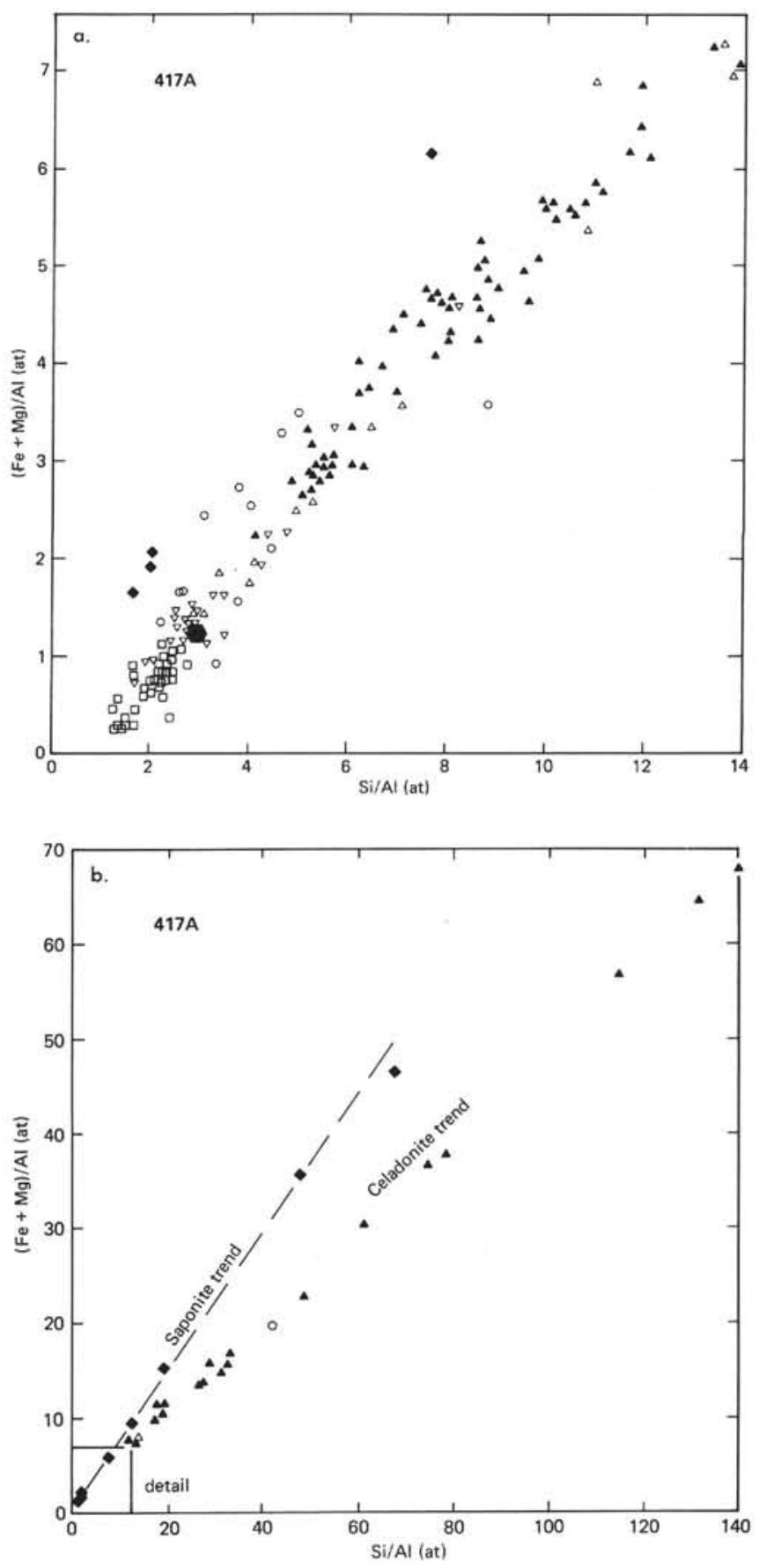

Figure 10. Diagram relating $(\mathrm{Fe}+\mathrm{Mg}) / \mathrm{Al}$ versus Si/Al for Hole $417 \mathrm{~A}$. Figure 10a shows the high-Al region, and Figure $10 \mathrm{~b}$ the lower-Al regions, with the field of the former diagram shown on the latter as a small rectangle. Symbols as in Figure 8. Note the abundance of high-Al clays.

noteworthy because chlorite has not been reported from younger DSDP basalts but is known from dredged basalts (Humphris and Thompson, 1978) where it appears to be related to hydrothermal activity (Tomasson and Kristmannsdottir, 1972). The dredge-basalt chlorite and the samples from Hole 418A are different in composition - 


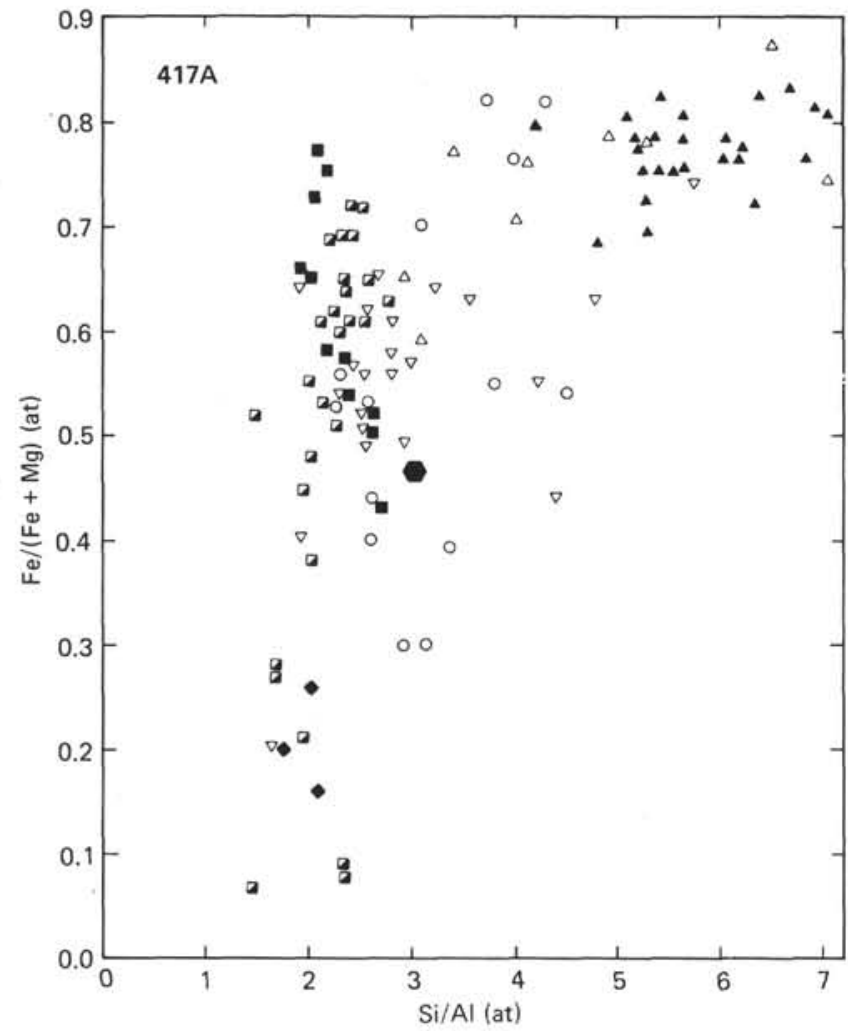

Figure 11. Diagram relating $\mathrm{Fe} /(\mathrm{Fe}+\mathrm{Mg})$ versus Si/Al for Hole 417A. Symbols as in Figure 8. Less aluminous samples, not shown here, have an $\mathrm{Fe} /(\mathrm{Fe}+\mathrm{Mg})$ ratio of between 0.7 and 0.8 .

those from Hole 418A being distinctly more magnesian and siliceous and less aluminous and $\mathrm{Fe}$-rich than those from the dredged basalts. In view of these wide compositional differences, it would be premature to speculate that the origins of these materials are related.

\section{K-feldspar}

An abundant phase in the highly altered part of Hole 417A is $\mathrm{K}$-feldspar, which, although preferentially formed on the site of plagioclase phenocrysts, also forms in the groundmass. Its formation is analogous to the widespread appearance in old oceanic sediments, especially those of volcanic origin, of authigenic K-feldspar (Donnelly and Nalli, 1973 and unpublished).

\section{Analcime, Apophyllite, and Zeolites}

Analcime is widespread in the highly altered portion of Hole 417A but much scarcer in Hole 417D and 418A. Compositionially (Table 2), it is nearly stoichiometric and its crystallography varies from nearly isometric to distinctly non-isometric, as evidenced by birefringence and the absence of certain X-ray peaks. Analcime generally occurs in vugs and veins, where it is a late mineral.

Apophyllite was found in Hole 418 (Pertsev and Rusinov, this volume). Its significance is unknown nor is it known whether its $\mathrm{F}$ content is normal.

The zeolites are most conspicuous in Hole 417A but much less so in Holes 417D and 418A. Chabazite is appar- ently confined to Hole $417 \mathrm{~A}$, but phillipsite and natrolite occur in all three holes. Most of the probe analyses of zeolites are assignable to phillipsite, with two compositional groups clearly visible - one Ca-rich, the other alkalic (Figure 12). Because of the difficulty in correlating X-ray and probe chemical data, it is possible that these represent both phillipsite and an unknown mineral. Although phillipsite has been identified by X-ray analysis, none of the probed specimens has been confirmed in this manner; thus it is possible that all these samples are of a mineral other than phillipsite. Assuming for the moment that all so-called phillipsite is correctly identified, then the principal compositional characteristics of interest are its high $\mathrm{Si}$ content (Figure 13) and its subdivision into two groups on the basis of $\mathrm{Ca}$ content (Figure 12). A further complication is an X-ray pattern of Pertsev and Rusinov (this volume) which is not of phillipsite but is apparently associated with a probed specimen whose composition places it in the low-Ca phillipsites.

Natrolite has been confirmed by X-ray analysis from Hole 417A (Pertsev and Rusinov, this volume; Donnelly, not published) and has been probed in Hole 417D. The probed sample (Table 2) (Pritchard, this volume) differs from stoichiometric natrolite in its higher $\mathrm{Al}$ content. In Hole 417A, natrolite occurs as acicular crystals growing on analcime in a vug lining. The presence of chabazite has been confirmed (Juteau et al., this volume) by X-ray analysis in several cores from Hole 417A. A Ca-rich mineral has been probed in different cores from the same hole by Mevel (this volume) and by Pertsev and Rusinov (this volume), but the composition of the probed mineral (Figure 13 , Table 2) differs markedly from stoichiometric chabazite in its higher $\mathrm{Al}$ content and more closely approximates a mesolite. Whatever the identity of the calcic zeolites, their existence is established. The significance of their occurrence is not known, but the observed abundance of calcite and the inferred chemical environment of alteration for Hole 417A (Donnelly et al., this volume) imply that calcic zeolites should not be formed, especially at very low temperatures.

\section{Carbonate Minerals}

Calcite is ubiquitous in all of the cores from Hole 417A and widespread in Holes 417D and 418A. Its existence reflects both $\mathrm{Ca}$ release during low-temperature alteration and the inferred production of $\mathrm{CO}_{3}{ }^{2-}$ ions as a consequence of hydrogen ion consumption during weathering. Dolomite (Pertsev and Rusinov, this volume) was found in two instances in Hole 418A. Manganocalcite was found (Pertsev and Rusinov, this volume; Humphris et al., this volume) in the uppermost cores of Hole 417A in intensely altered basalts. Aragonite was found (Donnelly, not published) in a vein in Hole 417D and replacing a plagioclase phenocryst in Hole 417A.

\section{Sulfides and Oxides}

Occurrences of these minerals are treated in greater detail elsewhere, in connection with their importance in S-isotope studies and with paleomagnetism. In summary, the dominant secondary sulfide is pyrite, which is not very conspicuous anywhere. Pyrite is confined to Holes 417D, 418A, and the lower, less altered thick pillow basalts of Hole 417A. 
TABLE 2

Unit Cell Contents for Site 417 and 418 Zeolites $^{a}$

\begin{tabular}{|c|c|c|c|c|c|c|c|c|c|c|}
\hline \multicolumn{11}{|l|}{ "Phillipsites" } \\
\hline $\mathrm{Si}$ & 12.1 & 12.2 & 12.0 & 11.8 & 12.1 & 11.7 & 11.4 & 11.1 & 11.5 & 12.1 \\
\hline $\mathrm{Al}$ & 4.22 & 4.01 & 4.65 & 3.68 & 4.13 & 4.43 & 4.98 & 5.07 & 4.66 & 4.32 \\
\hline $\mathrm{Ca}$ & 0.06 & 0.06 & 0.11 & 0.24 & 0.01 & 1.07 & 1.26 & 1.27 & 1.44 & 0 \\
\hline $\mathrm{Na}$ & 1.37 & 1.52 & 0.53 & 0 & 1.37 & 0.64 & 0.32 & 0.84 & 0.28 & 1.00 \\
\hline $\mathrm{K}$ & 1.07 & 1.29 & 1.05 & 2.96 & 1.85 & 0.96 & 0.69 & 0.93 & 0.78 & 1.75 \\
\hline Hole & 417D & 417D & 417D & $418 \mathrm{~A}$ & $417 \mathrm{~A}$ & 417D & $418 \mathrm{~A}$ & $418 \mathrm{~A}$ & $418 \mathrm{~A}$ & 417D \\
\hline Reference $^{\mathrm{b}}$ & (1) & (1) & (1) & (2) & (2) & (3) & (3) & (3) & (3) & (3) \\
\hline \multicolumn{7}{|l|}{ "Phillipsites" } & \multicolumn{3}{|c|}{ "Mesolite?" } & "Natrolite?" \\
\hline $\mathrm{Si}$ & 11.7 & 11.9 & 11.5 & 10.6 & 10.7 & 10.9 & 8.35 & 9.10 & & 23.0 \\
\hline $\mathrm{Al}$ & 4.59 & 4.40 & 4.29 & 5.65 & 5.57 & 5.45 & 6.55 & 6.04 & & 17.4 \\
\hline $\mathrm{Ca}$ & 0.09 & 0.08 & 0.20 & 1.00 & 1.11 & 1.24 & 2.95 & 2.52 & & 2.40 \\
\hline $\mathrm{Na}$ & 1.22 & 1.26 & 4.00 & 2.65 & 1.40 & 1.31 & 0.82 & 0.41 & & 11.6 \\
\hline $\mathrm{K}$ & 1.89 & 1.79 & 0.81 & 0.08 & 0.85 & 0.05 & 0 & 0.03 & & 0 \\
\hline Hole & 417D & 417D & $418 \mathrm{~A}$ & $417 \mathrm{~A}$ & $417 \mathrm{~A}$ & $417 \mathrm{~A}$ & $417 \mathrm{~A}$ & $417 \mathrm{~A}$ & & $418 \mathrm{~A}$ \\
\hline Reference $^{b}$ & (3) & (3) & (1) & (3) & (3) & (3) & (1) & (3) & & (2) \\
\hline
\end{tabular}

Analcime

$\begin{array}{lcccc}\mathrm{Si} & 2.32 & 2.34 & 2.32 & 2.40 \\ \mathrm{Al} & 1.23 & 1.18 & 1.19 & 1.14 \\ \mathrm{Ca} & 0.01 & 0.0 & 0 & 0.01 \\ \mathrm{Na} & 1.00 & 1.10 & 1.12 & 0.93 \\ \mathrm{~K} & 0 & 0 & 0.01 & 0.0 \\ \text { Hole } & 418 \mathrm{~A} & 418 \mathrm{~A} & 417 \mathrm{~A} & 417 \mathrm{~A} \\ \text { Reference }^{\mathrm{b}} & (2) & (2) & (2) & (4)\end{array}$

a On the basis of 32 oxygens for "phillipsite," 80 oxygens for "natrolite," 30 oxygens for "mesolite," and 7 oxy$b$ gens for analcime.

References: $(1)=$ Pertsev and Rusinov, this volume; (2) = Pritchard, this volume; (3) = Mevel, this volume; and (4) $=$ Schneidegger and Stakes, this volume.

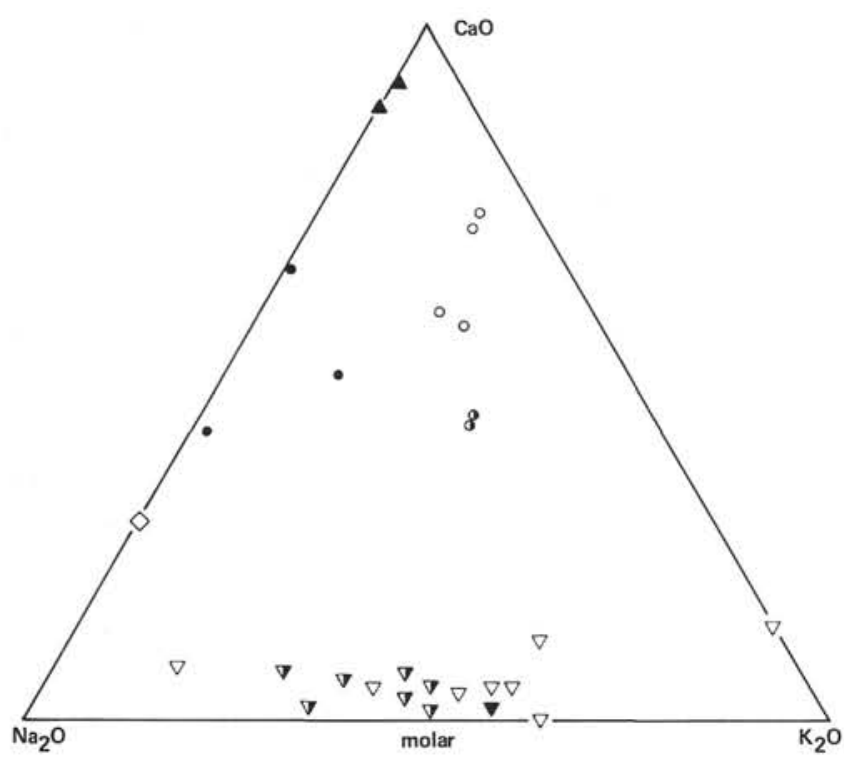

Figure 12. Triangular diagram relating molar $\mathrm{CaO}, \mathrm{Na}_{2} \mathrm{O}$, and $\mathrm{K}_{2} \mathrm{O}$ for zeolites from Sites 332, 335, 417, and 418. Open symbols represent samples from Holes $417 D$ and $418 \mathrm{~A}$, solid symbols samples from Hole $417 \mathrm{~A}$, and half-filled symbols samples from Sites 332 and 335 . Upright triangles represent Ca-rich zeolites, the diamond represents a natrolite, the circles Ca-rich phillipsites, and the inverted triangles low-Ca phillipsites.
Elsewhere in Hole 417A, and in scattered instances in the other two holes, hydrated iron oxide (goethite) is dominant. These mineral groups are mutually exclusive in their occurrence.

\section{EFFECT OF AGE ON MINERAL ASSEMBLAGES}

Young basalts (Site 332, 3.5 m.y.; Site 335, 13 m.y.) are fresh, with visible alteration confined generally to fractures, veins, and other originally open spaces. The alteration consists dominantly of conversion of some glass to palagonite and the growth of new smectite in open spaces. The smectite spans the compositional range from saponite to celadonite and possibly consists of mixed-layer clays. This clay has a very low $\mathrm{Al}$ content, consistent with its presumed origin as the transported and reconstituted derivative of the non-aluminous phases most susceptible to initial weathering. Older mineral assemblages tend toward discrete groupings around the end members of this range, with intermediate compositions scarce. Also, the older clay minerals tend to be higher in $\mathrm{Al}$ in general, but the principal clays of Holes 417D and 418A are still very low in $\mathrm{Al}$ when compared with common terrestrial analogues. The very thoroughly altered Hole 417A samples contain very little end-member saponite, and this is mostly confined to the least altered portion of the hole. Hole $417 \mathrm{~A}$ also has an abundance of highly aluminous minerals, reflecting the almost complete breakdown of basalt to secondary minerals some of which must accommodate the $\mathrm{Al}$ of the original basalt. 


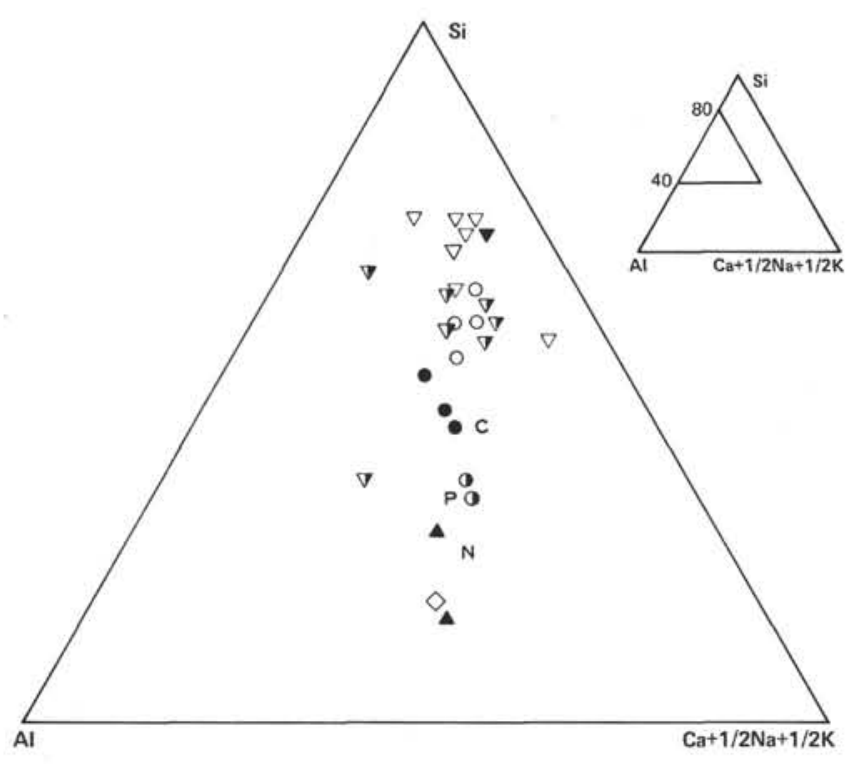

Figure 13. Triangular diagram relating $\mathrm{Si}, \mathrm{Al}$ and $(\mathrm{Ca}+1 / 2$ $\mathrm{Na}+1 / 2 \mathrm{~K})$ for zeolites from Sites 332, 335, 417, and 418. Symbols as in Figure 12. $C, P$, and $N$ represent ideal compositions for chabazite, phillipsite and natrolitemesolite-scolecite. Inset diagram shows position of large diagram on complete triangular diagram.

The relationship between original morphology (meaning abundance and distribution of fractures and their effect on permeability to altering fluids) and alteration mineralogy is seen in Figure 14, which relates the $\mathrm{Si} / \mathrm{Al}$ ratio of the clay minerals to morphology. The breccias and thin upper flows have lower $\mathrm{Si} / \mathrm{Al}$ ratios, implying more complete alteration. The highest $\mathrm{Si} / \mathrm{Al}$ ratios, implying freshness and similarity to the less altered basalts of Holes 417D and 418A, are seen in the massive basalts and thick pillow basalts of Units 18 and 16 . The lowest breccias, whose hydration and $\mathrm{K}$ contents show that they are highly altered, again have the characteristic low $\mathrm{Si} / \mathrm{Al}$ ratios.

It is not clear that any minerals seen during Legs 51 through 53 must be explained by temperatures considerably above the very low temperatures characteristic of the sea floor. Oxygen isotope evidence (Muehlenbachs, this volume; Lawrence, this volume) is equivocal: the $\mathrm{O}^{18}$ values are more strongly positive than is the case for contemporary sea-floor basalts, suggesting mixing of sea water with the basalt (Muehlenbachs, this volume). However, equilibration temperatures are not directly calculable from these values, because the $\mathrm{O}^{18}$ value of the water involved in alteration is not known (it might have been stagnant sea water) nor is the relative amount of water. The mineral assemblages suggest but do not require slightly higher temperatures (chlorite, some of the zeolites). The question of temperature must remain open, but no present evidence demands high temperatures.

Temperatures of alteration of very young basalts are uniformly close to the ambient sea floor temperature of about $0^{\circ} \mathrm{C}$. If the basalts are fractured, the temperature gradients remain very low so long as the fractures remain open sufficiently to permit the passage of water. The lack of mineral zonation in Hole 418A suggests that a very low temperature gradient existed in that hole. As long as the basalts are

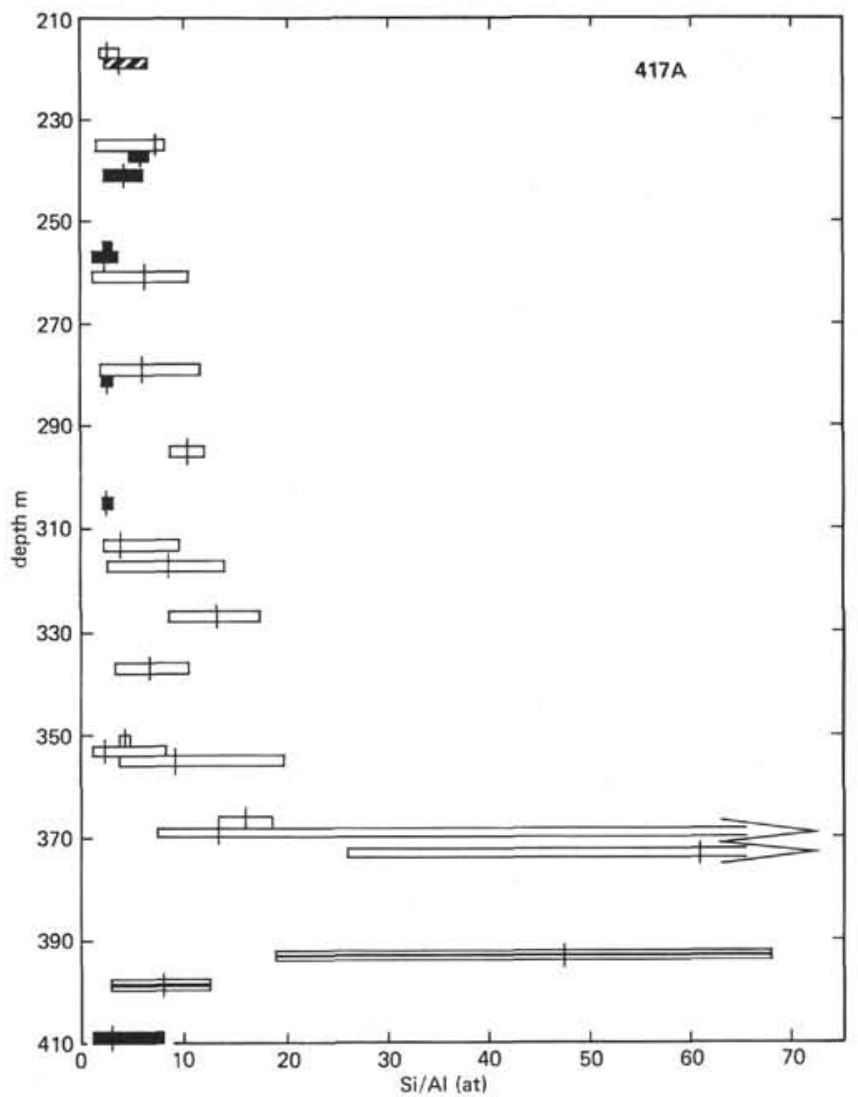

Figure 14. Diagram relating the $\mathrm{Si} / \mathrm{Al}$ ratio of clays versus depth in Hole 417 A. Bars show range of values and median value, except that some lower groups extend to far higher Si/Al ratios. Open bars represent pillow lavas, solid bars are breccias, bars with solid central lines are massive basalts, and the half filled bar represents a thin basalt-breccia. Note the relationship between the Al content of clays and the intensity of alteration, as well as original lithology.

exposed to sea water, the temperature to the bottom of the fractured zone must be about $0^{\circ} \mathrm{C}$. When the basalts are covered by sediment, however, the temperature of the basalt pile can rise even though there may be no gradient within the fractured basalts. It is not known how long the crust retains heat, but it would appear that the period must be of an order considerably greater than $10 \mathrm{~m} . \mathrm{y}$., after which most crust is covered with sediment. Thus, the period for attaining maximum temperature by the fractured basalts of Layer 2 might be several million years after their formation, and at that time the temperature might be several tens of degrees. Whatever the maximum temperature attained, it was insufficient to cause formation of any mineral assemblage normally associated with hydrothermal processes (such as actinolite).

\section{CHEMISTRY}

As shown in the summary of Table 3 and in Figure 15, there is a clear increase in the degree of hydration with age of the crust. There is also an increase in $\mathrm{CO}_{2}$ (Figure 16), presumably resulting from continued breakdown of basalt during hydration with the concomitant release of $\mathrm{Ca}^{2+}$ ions and conversion of $\mathrm{HCO}^{3-}$ to $\mathrm{CO}_{3}{ }^{2-}$ ions. There is, how- 

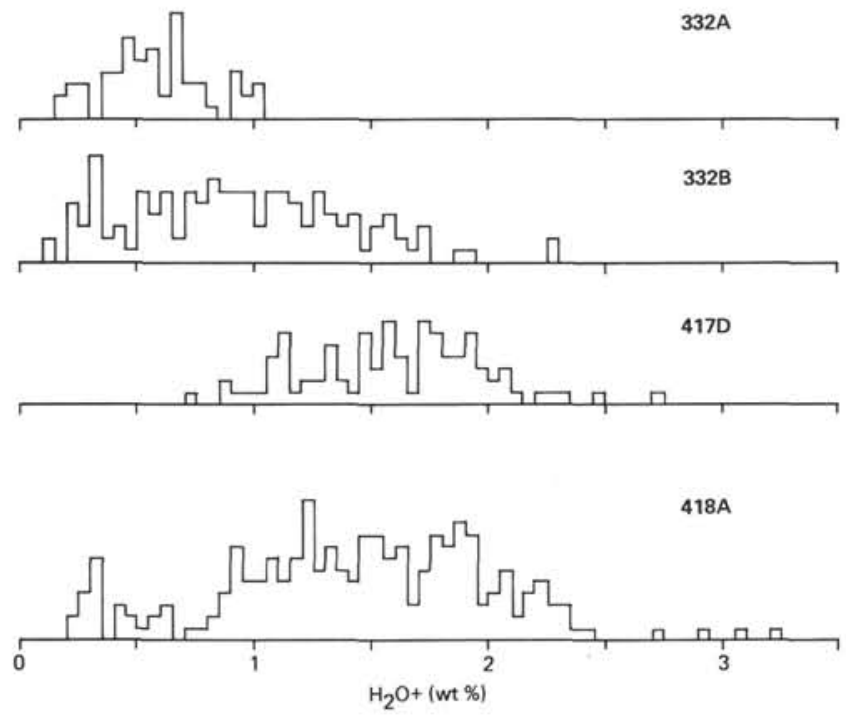

Figure 15. Histogram of $\mathrm{H}_{2} \mathrm{O}^{+}$values for Holes $332 \mathrm{~A}$, $332 B, 417 D$, and $418 A$.
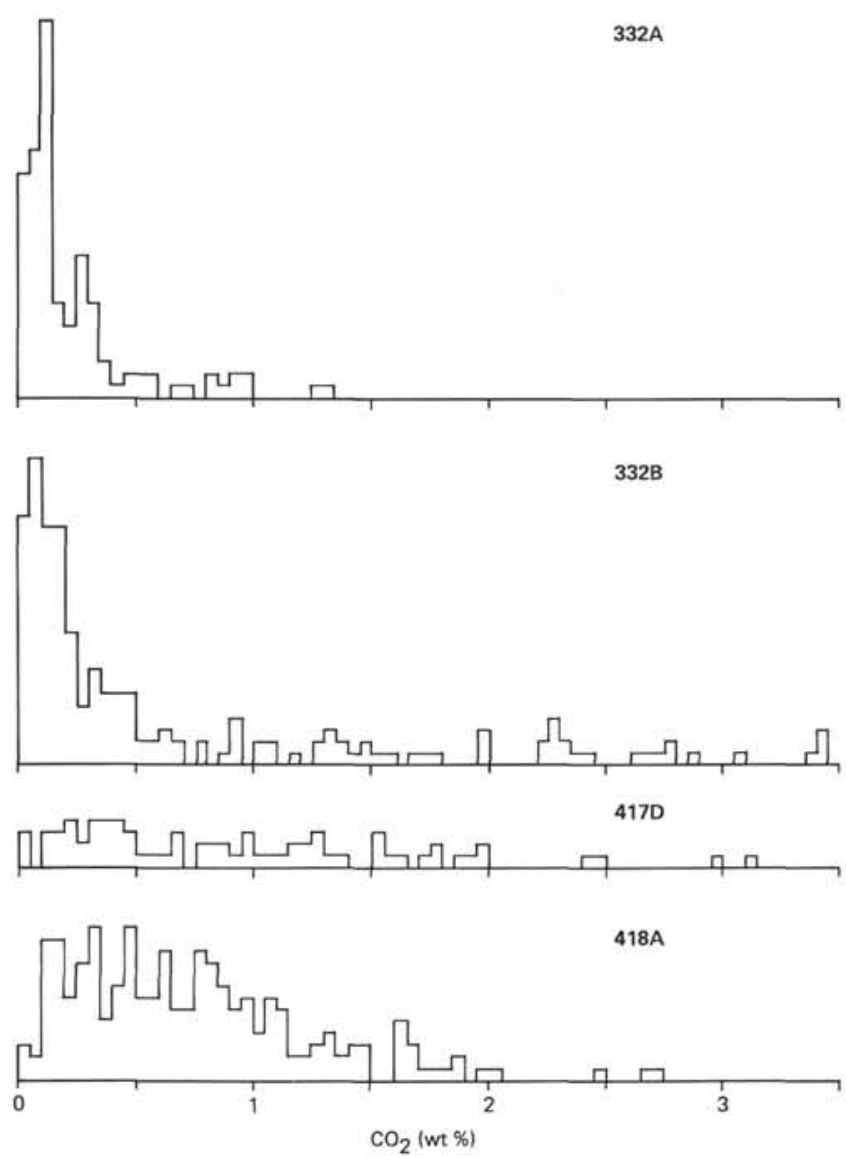

Figure 16. Histogram of $\mathrm{CO}_{2}$ values for Holes $332 \mathrm{~A}, 332 \mathrm{~B}$, $417 D$, and $418 A$.

ever, no clear relationship between depth within the crust and the degree of hydration (Figure 17). Rather, the most hydrated portions are the most fractured or brecciated portions. Even in Hole 417A, the thick pillow basalts of Unit
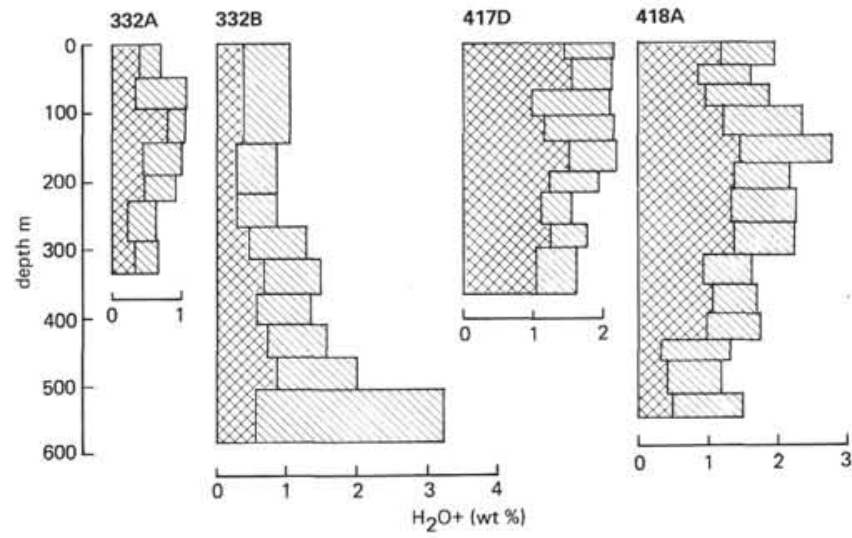

Figure 17. Diagram showing $\mathrm{H}_{2} \mathrm{O}^{+}$values versus depth for Holes $332 A, 332 B, 417 D$, and $418 A$. Each box shows the standard deviation limits for samples from five cores.

16 and the massive basalts of Unit 18 are nearly unaltered, whereas the shallower thin basalts and hyaloclastites and the deepest unit (Unit 19), which is a breccia, are highly altered.

Oxidation (Figure 18) seems to increase with $\mathrm{H}_{2} \mathrm{O}$ in very young basalts, but there is no clear increase in oxidation in the old basalts of Sites 417 and 418 beyond that observed in the 13-m.y. basalts of Site 335. Although basalts continue to acquire water long after burial by sediment, this water has little oxidation capacity and the overlying sediment would probably itself serve as a sink for oxidation. Thus, we would not expect continued oxidation of sediment-covered basalt, unless some kind of tectonic event occurs allowing fresh sea water to penetrate the basalt crust at a later time. Where the crust is exposed to sea water for an unusually

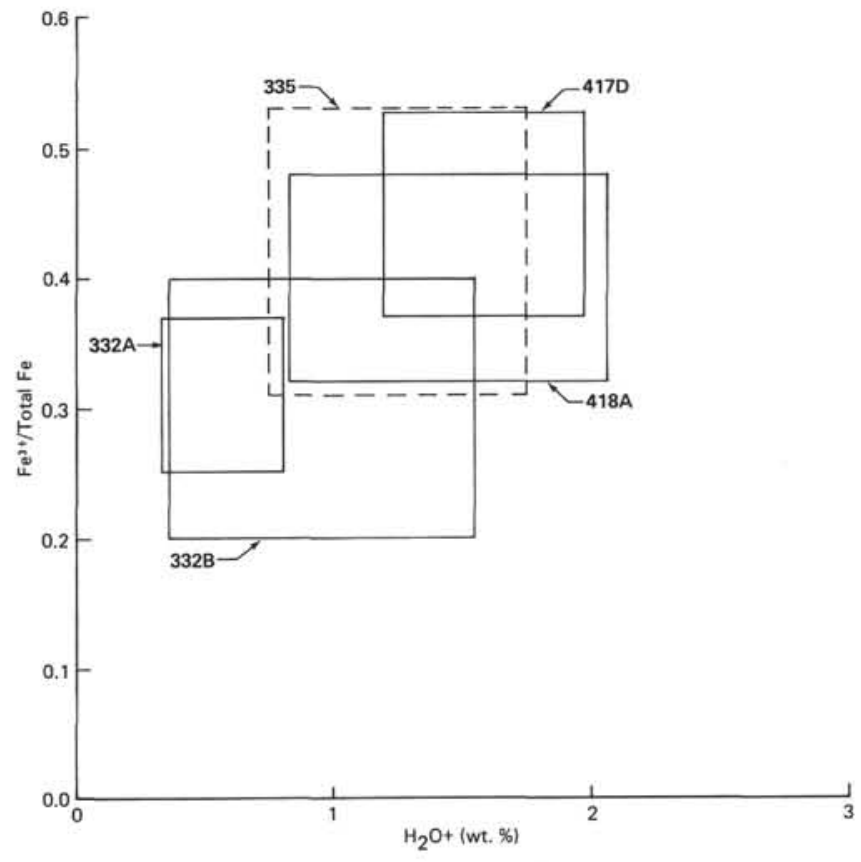

Figure 18. Diagram showing $\mathrm{Fe}^{3+} /$ Total $\mathrm{Fe}$ versus $\mathrm{H}_{2} \mathrm{O}^{+}$ for Holes 332A, 332B, 335, 417D, and 418A. Boxes represent standard deviation limits. 
long period, as was the case in Hole 417A, the oxidation is nearly complete. A problem of interest here is the relatively reduced, though thoroughly altered, character of the lowest unit encountered in Hole 417A. One might speculate that this unit was exposed for a brief period to reducing bottom waters, since strongly reduced sediments are found at this level immediately to the west in Hole 417D.

The $\mathrm{K}$ content of these rocks is high in only one case: the highly altered basalt of Hole 417A (see Donnelly, Thompson, and Salisbury, this volume). In other cases (Figure 19), although there are individual high values, the average $\mathrm{K}$ values appear to be relatively normal. As shown in Table 3a, the ratio of the average $\mathrm{K}$ content in basalt to that in fresh glass for each hole is nearly identical in Holes 332A, 332B, 417D, and 418A. The older holes happened to penetrate a less potassic basalt than the younger, and in consequence have basalts of somewhat lower average $\mathrm{K}$ values even though their average level of alteration, as seen by the degree of hydration, is higher. As was the case for oxidation, the pore water in fractured basalt which is sealed above by sediment has little $\mathrm{K}$ to add to the basalt, and the relatively low $\mathrm{K}$ values of the older basalt reinforce the view, suggested by their oxidation levels, that the water in contact with the older crust in fractures is stagnant.

\section{Minor Elements and the Alteration Process}

In connection with the process of alteration, several minor elements have been investigated (Donnelly et al., this volume; Joron et al., this volume; Humphris et al., this volume; Emmermann and Puchelt, this volume; Hart and Staudigel, this volume; and Staudigel, et al., this volume).

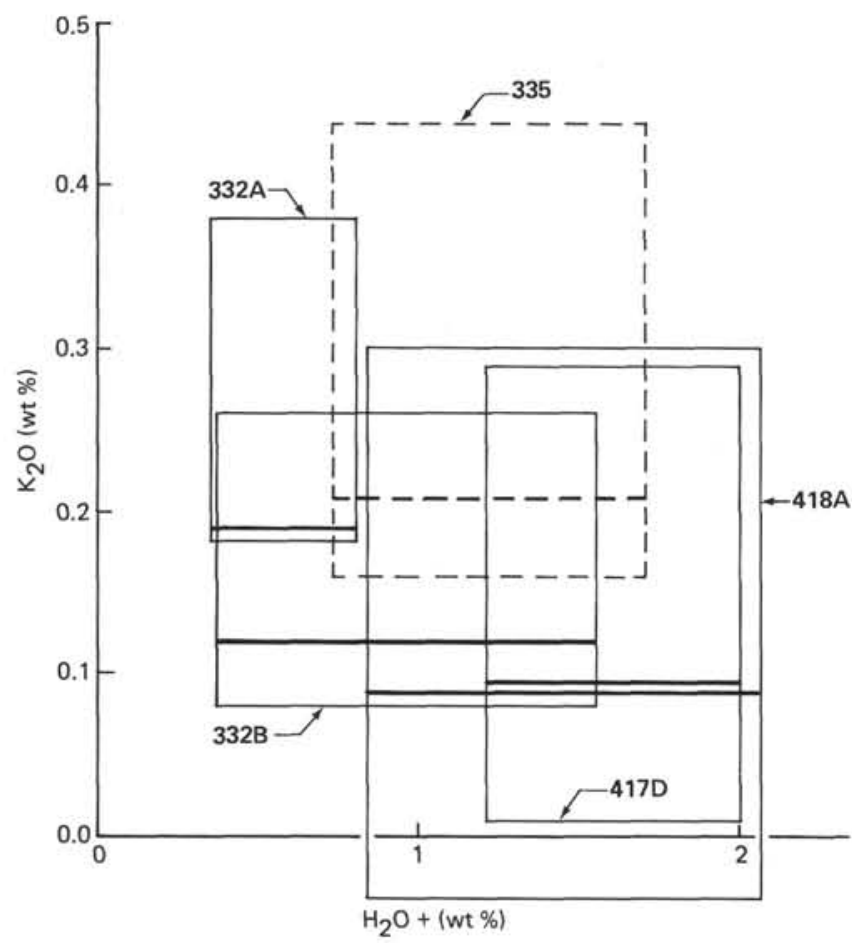

Figure 19. Diagram showing $\mathrm{K}_{2} \mathrm{O}$ versus $\mathrm{H}_{2} \mathrm{O}^{+}$for Holes $332 \mathrm{~A}, 332 \mathrm{~B}, 335,417 \mathrm{D}$, and $418 \mathrm{~A}$. Boxes represent standard deviation limits. Horizontal line in each box shows the average glass $\mathrm{K}_{2} \mathrm{O}$ value for each hole.
Questions of interest to which minor element values can contribute fall into two categories: budgetary constraints on the acquisition of elements from sea water, and conditions of alteration of rocks as revealed by minor element distribution.

\section{Rare Earth Elements (REE)}

In addition to REE values obtained in connection with studies of magma genesis (Langmuir et al., this volume; and Shimizu et al., this volume), we have made several REE determinations by neutron activation methods (see Emmermann and Puchelt, this volume) of highly altered rocks from Hole 417A (Table 4; Figures 20 and 21). As Figure 20 illustrates, rocks with a fairly high degree of alteration, as shown by $\mathrm{K}_{2} \mathrm{O}$ contents, have REE patterns very little different from those of normal, unaltered basalt. The stability of the REE during weathering is shown convincingly by these results. Two "red-brown basalts" are included in this group. These basalts have somewhat higher $\mathrm{Ti}, \mathrm{Al}$, and $\mathrm{Zr}$ contents, leading to the conclusion that they represent a residuum from which other constituents have been extracted during the alteration process (Donnelly et al., this volume). The more severely altered of these (Sample 417A-24-2, $58-63 \mathrm{~cm}, \mathrm{~F}$ ), ${ }^{2}$ with a $\mathrm{K}_{2} \mathrm{O}$ content of 7.50 per cent, a $\mathrm{TiO}_{2}$ content of 2.16 per cent, and a $\mathrm{Zr}$ content of $170 \mathrm{ppm}$, also has a markedly higher REE content, especially the light rare earths, consistent with its high content of $\mathrm{K}, \mathrm{Ti}$, and $\mathrm{Zr}$.

At the other extreme are the hyaloclastites of Hole 417A, which are distinctive in their low $\mathrm{Ti}$ and $\mathrm{Zr}$ contents and their very low Y contents. These materials are thought to represent mixtures of hydrated basalt glass and transported constituents. Their Y and REE values are extremely low, and their $\mathrm{Ti}, \mathrm{Zr}, \mathrm{Hf}, \mathrm{Cr}$, and $\mathrm{Sc}$ values are distinctly lower than in normal basalt. If hyaloclastite represents totally transported material (i.e., "precipitated rock"), a reasonable amount of $\mathrm{Ti}$ and $\mathrm{Zr}$ must have been transported in aqueous solution. If the hyaloclastite represents a mixture of glass altered in situ and precipitated materials carried by aqueous solution, the REE and Y of the glass must have been extracted because their depletion factors are far greater than those of other, also presumably inert, elements. Hart et al. (this volume) show that palagonite coexisting with glass is depleted in REE and other inert elements, but the depletion factors in each case are highly uniform, suggesting that depletion is largely a dilution by added phases, principally water. Normal palagonitization apparently has little effect on these inert elements, but the more extreme process which has produced the highly altered hyaloclastites of Hole 417A has clearly resulted in extensive "inert" element movement. It is very difficult to explain the extremely low values of $\mathrm{Y}$ and REE by any mechanism other than selective removal. The extreme insolubility of all these elements in pure water raises the question as to what chemical environment could have been responsible for such extreme leaching. Whether low $p \mathrm{H}$ or the presence of complexing anion species (such as carbonate) might have been important is not known, and the question must be left open.

\footnotetext{
${ }^{2} \mathrm{~F}$ refers to relatively fresh portion of the sample as determined by a grayer or greener color.
} 
TABLE 3A

Average Values of $\mathrm{H}_{2} \mathrm{O}^{+}, \mathrm{K}_{2} \mathrm{O}$, and $\mathrm{Fe}^{3+} /$ Total $\mathrm{Fe}$ for Sites 332, 335, 417, and 418

\begin{tabular}{lcrccc}
\hline Hole & $332 \mathrm{~A}$ & $332 \mathrm{~B}$ & 335 & $417 \mathrm{D}$ & $418 \mathrm{~A}$ \\
\hline $\mathrm{H}_{2} \mathrm{O}^{+}$ & $0.58 \pm 0.23$ & $0.96 \pm 0.59$ & $1.22 \pm 0.48$ & $1.59 \pm 0.39$ & $\begin{array}{c}1.45 \pm 0.61 \\
\end{array}$ \\
& $(60)$ & $(139)$ & $(28)$ & $(91)$ & $(220)$ \\
$\mathrm{K}_{2} \mathrm{O}$ & $0.28 \pm 0.10$ & $0.17 \pm 0.09$ & $0.30 \pm 0.14$ & $0.15 \pm 0.14$ & $0.13 \pm 0.17$ \\
rock & $(60)$ & $(139)$ & $(28)$ & $(91)$ & $(220)$ \\
$\mathrm{K}_{2} \mathrm{O}$ & $0.19 \pm 0.03$ & $0.12 \pm 0.05$ & $0.21 \pm 0.04$ & $0.095 \pm 0.015$ & $0.091 \pm 0.027$ \\
glass & $(83)$ & $(48)$ & $(95)$ & $(79)$ & $(112)$ \\
$\mathrm{Fe}^{3+}$ & $0.31 \pm 0.06$ & $0.30 \pm 0.10$ & $0.42 \pm 0.11$ & $0.45 \pm 0.08$ & $0.40 \pm 0.08$ \\
Total $\mathrm{Fe}$ & $(60)$ & $(139)$ & $(28)$ & $(91)$ & $(220)$ \\
\hline
\end{tabular}

TABLE 3B

Comparative Minor Element Data for Sites 332, 417, and 418

\begin{tabular}{lcccc}
\hline Hole & $332 \mathrm{~A}$ & $332 \mathrm{~B}$ & $417 \mathrm{D}, 418 \mathrm{~A}$ & $417 \mathrm{~A}$ \\
\hline $\mathrm{B}$ & $9 \pm 6(9)$ & $11 \pm 13(49)$ & $21 \pm 16(17)$ & $63 \pm 37(28)$ \\
$\mathrm{Li}$ & $5 \pm 3(24)$ & $11 \pm 8(152)$ & $10 \pm 7(113)$ & $29 \pm 18(28)$ \\
$\mathrm{Rb}$ & $5.8 \pm 2.9(82)$ & $4.2 \pm 2.4(363)$ & $2.3 \pm 5.2(159)$ & $16.9 \pm 16.9(38)$ \\
$\mathrm{Ba}$ & $79 \pm 108(73)$ & $44 \pm 27(386)$ & $13.6 \pm 11.0(17)$ & $69 \pm 103(20)$ \\
$\mathrm{St}$ & $115 \pm 15(85)$ & $100 \pm 36(394)$ & $116 \pm 23(304)$ & $131 \pm 59(66)$ \\
\hline
\end{tabular}

Note: Table 3a was prepared using a selected subset of data from samples obtained from Leg 37 and Leg 51 through 53. For Leg 37, data were rejected where the investigator had not reported interlaboratory comparison data for all three variables. Numbers show average, standard deviation, and number of data points (in parentheses).

\section{Strontium}

Measured values of $\mathrm{Sr}$ (Table $3 \mathrm{~b}$ ) show that this element is little affected by alteration in oceanic basalts. Even the severely altered basalts of Hole 417A are only slightly enriched in this element.

\section{Lithium and Boron}

These elements are commonly enriched in basalts exposed to sea water for long periods. Their values show enrichment in the severely altered basalts of Hole 417A, but the degree of enrichment is less than that of $\mathrm{K}$.

\section{Rubidium}

As can be seen in Figure 22, the Rb concentration varies with $\mathrm{K}$ content, especially in the severely altered basalts of Hole 417A. Part of this coherence, including its greater abundance in the fresh basalts from Holes $332 \mathrm{~A}$ and 332B may be magmatic, but there is also coherent behavior during alteration. Rubidium is especially of interest because the $\mathrm{K} / \mathrm{Rb}$ ratios do not approach the sea-water ratio, but are about eight times smaller than this value. If both $\mathrm{Rb}$ and $\mathrm{K}$ are being removed from "normal" sea water, this might imply that the efficiency of $\mathrm{Rb}$ removal is about eight times that of $\mathrm{K}$ removal. An alternative explanation is that the $\mathrm{Rb}$ is derived from water from another source, such as juvenile water or water carrying juvenile $\mathrm{Rb}$ - a suggestion inconsistent with $\mathrm{Sr}$ isotope systematics. Objections to invoking such mysterious water are that the isotope results discussed elsewhere point to the water of alteration being nearly identical with sea water. Thus, unless there is a special $\mathrm{Rb}$ source, the probability is that far more water moved through this rock than had been estimated by Donnelly et al. (this volume). The $\mathrm{K}-\mathrm{Rb}$ relationships for Holes $332 \mathrm{~A}$ and $332 \mathrm{~B}$ (Aumento, Melson, et al., 1977) show that the more highly altered basalts (which are far less altered than the Hole 417A samples) approach the same $\mathrm{K} / \mathrm{Rb}$ ratios. This suggests that the $\mathrm{K} / \mathrm{Rb}$ ratio of $110-\mathrm{m}$.y.-old sea water might not have been very different from the present value. The data lack the resolution, however, to prove or disprove the suggestion of Hart and Staudigel (this volume) that the $\mathrm{K} / \mathrm{Rb}$ ratio of sea water 110 m.y. ago might have been smaller than the present value by a factor of 1.4.

\section{Cesium}

Unfortunately, far too few determinations are available for this element, and its content in fresh basalts is not reliably established. Figure 23 shows the relationship between $\mathrm{K}$ and Cs in Holes 417A, 417D, and 418A. Although the data scatter widely, the Cs concentration tends to vary with $\mathrm{K}$ content. The more altered samples have $\mathrm{K} / \mathrm{Cs}$ ratios considerably less than the sea-water ratio. As for $\mathrm{Rb}$, either there is a discrete Cs source, or, if the Cs comes from unmodified sea water with present-day Cs values, the Cs is preferentially taken up in the basalt during weathering. Hart and Staudigel (this volume) suggest that Cretaceous oceanic water had a Cs value about 4.5 times greater than at present, relative to $\mathrm{K}$. This difference would explain part of the discrepancy between $\mathrm{K}$ and Cs in weathered rocks, but the difference is closer to 30 times as great. Unfortunately, information on the Cs values of recently weathered basalts is not extensive, and this question cannot be pursued further.

\section{Barium}

The correspondence between the Ba concentration and the $\mathrm{K}$ content in either fresh or altered rocks (Figure 24) is less obvious than that for $\mathrm{Rb}$ or $\mathrm{Cs}$. The increase in $\mathrm{K}$ in highly altered rocks (Hole 417A) is accompanied by an increase in $\mathrm{Ba}$, and the $\mathrm{K} / \mathrm{Ba}$ ratio of the most highly altered rocks is about $1 / 30$ that of sea water. Again, the Ba source is not known. If it comes from sea water, the efficiency of $\mathrm{Ba}$ removal must be about 30 times that of $\mathrm{K}$ removal, placing important constraints on the minimum amount of water moved through the rock. It is possible that the bottom waters were especially enriched in $\mathrm{Ba}$, however. Corliss et al. (1979) found $\mathrm{Ba}$ values about three times as great as that used to construct the sea-water ratio of Figure 24. If these high values apply, they would reduce the discrepancy by two-thirds. However, the measurements of Corliss et al. (1979) also showed that this special high-Ba-content water was immediately diluted to normal sea water values. Therefore, unless the alteration at Hole 417A took place in hot ascending waters with an important juvenile component, as 

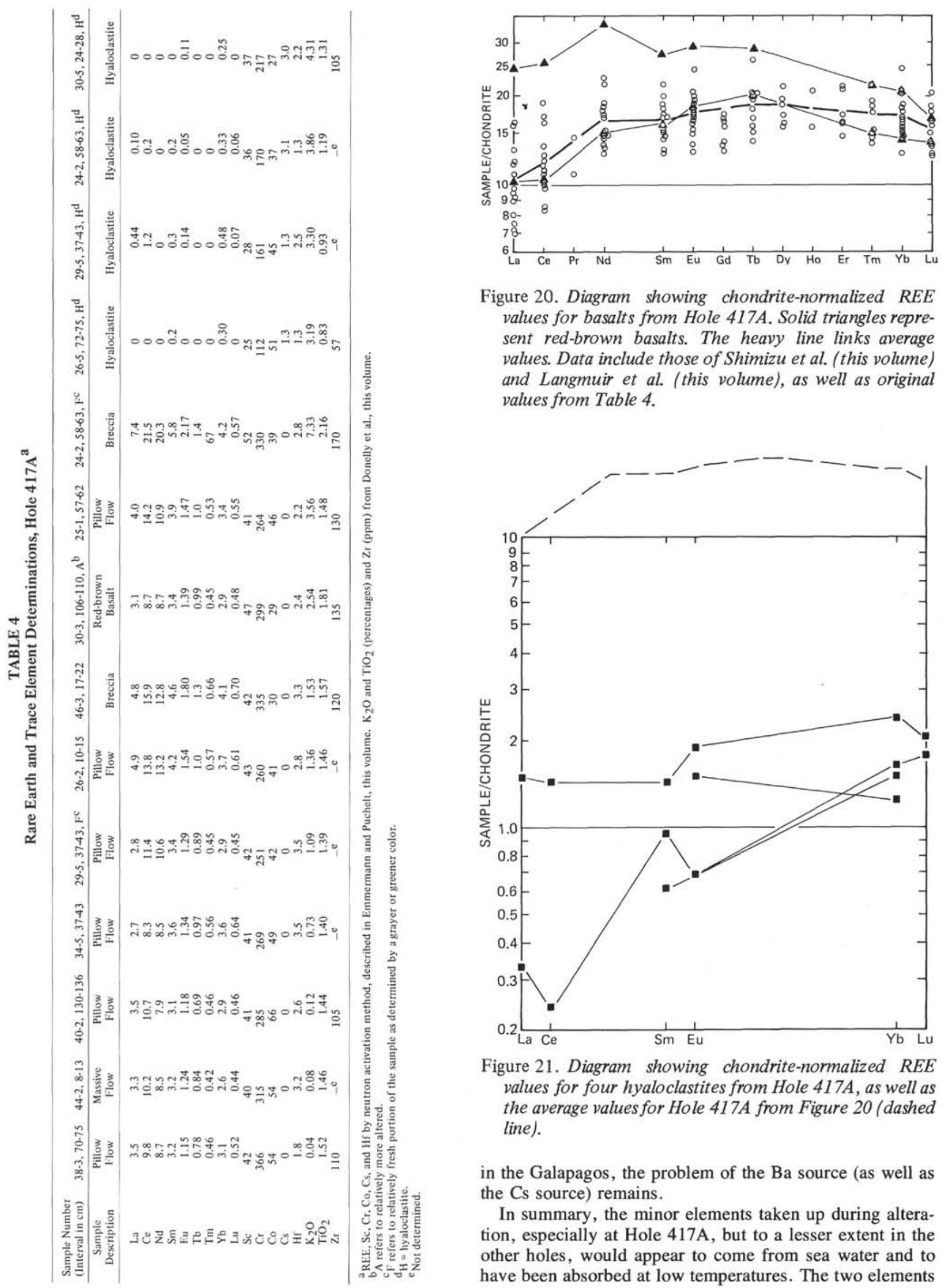

Figure 20. Diagram showing chondrite-normalized REE values for basalts from Hole 417 A. Solid triangles represent red-brown basalts. The heavy line links average values. Data include those of Shimizu et al. (this volume) and Langmuir et al. (this volume), as well as original values from Table 4.

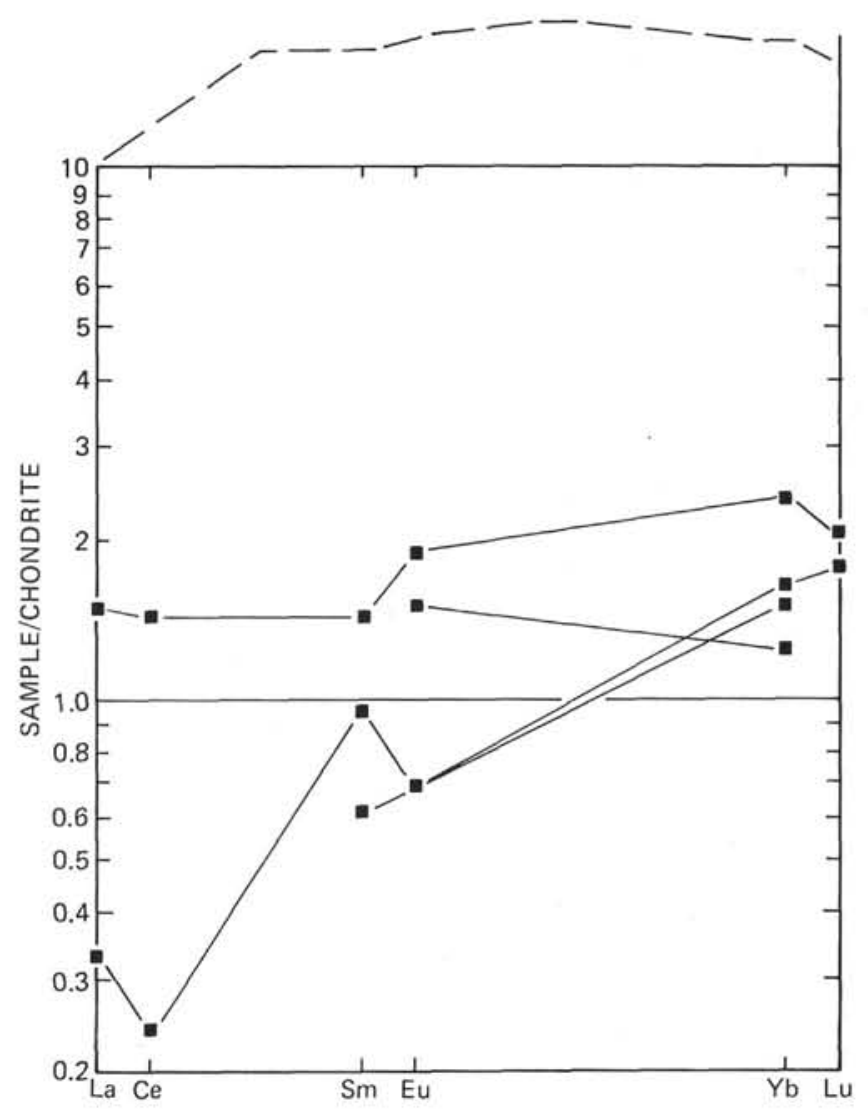

Figure 21. Diagram showing chondrite-normalized REE values for four hyaloclastites from Hole 417A, as well as the average values for Hole 417A from Figure 20 (dashed line).

in the Galapagos, the problem of the Ba source (as well as the Cs source) remains.

In summary, the minor elements taken up during alteration, especially at Hole $417 \mathrm{~A}$, but to a lesser extent in the other holes, would appear to come from sea water and to have been absorbed at low temperatures. The two elements 


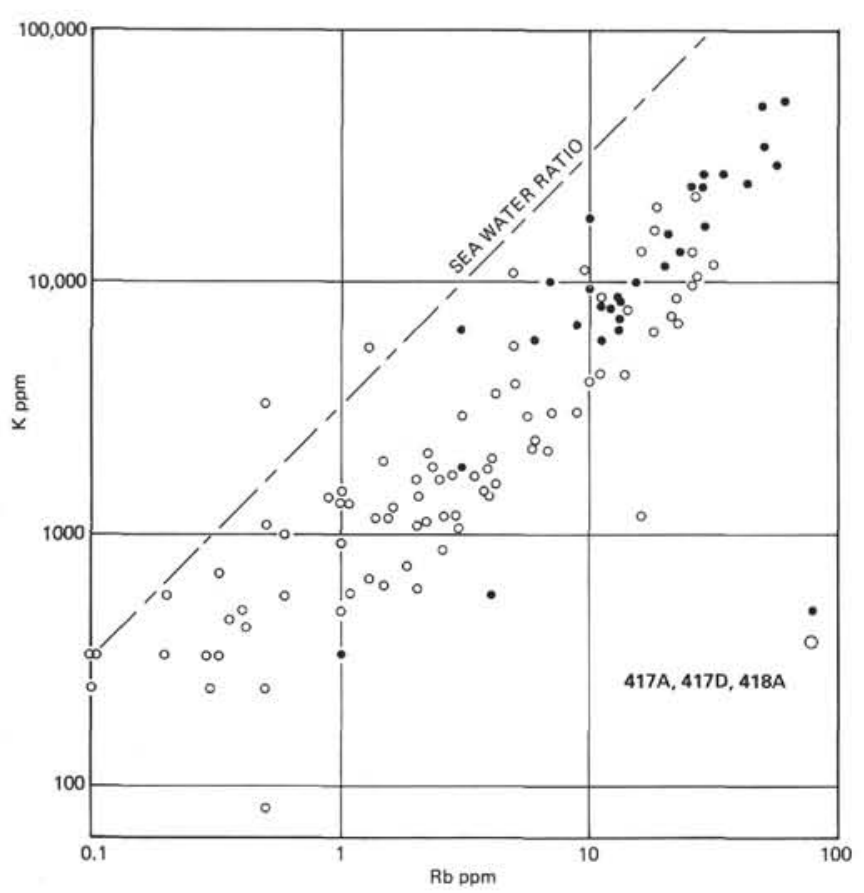

Figure 22. Diagram relating $\log K$ versus $\log R b$ for Sites 417 and 418. Solid symbols represent samples from Hole $417 \mathrm{~A}$ and open symbols samples from Holes $417 \mathrm{D}$ and $418 \mathrm{~A}$. Dashed line represents the $K / R b$ ratio of sea water.

enriched the most $-\mathrm{Ba}$ and $\mathrm{Cs}$ - are represented by too few analyses to draw firm conclusions about their present distribution. However, in each case they appear to represent an absorption process about 30 times more efficient than that for $\mathrm{K}$, assuming sea water of the present composition. Rubidium is the best known of the enriched elements, and its absorption is about eight times as efficient as that for $\mathrm{K}$. Very likely these elements all came from sea water of a composition sufficiently close to modern sea water as to suggest their preferential removal.

Hart and Staudigel (this volume) propose that the alteration process at Hole 417A occurred at a very young age, on the basis of radiometric alteration dates that are not essentially different from the age of the crust. This young age poses the following problem: If the sea water which moved through the upper levels of Hole 417A was of sufficient quantity to satisfy the $\mathrm{Ba}$ and $\mathrm{Cs}$ uptake based on modern ocean $\mathrm{K} / \mathrm{Ba}$ and $\mathrm{K} / \mathrm{Cs}$ ratios, and if the basic reasoning of Donnelly et al. (this volume) concerning $\mathrm{K}$ uptake is valid, and if the time available for the alteration process is 100,000 years, and if the upper 200-meter column of rock was all that was altered (mixing some liberal and some conservative assumptions), then what was the amount of water moved across the basalt/sea bottom interface per unit time? Assuming a 14 per cent porosity due to fractures (Donnelly, Thompson, and Salisbury, this volume), then a $1 \mathrm{~cm}^{2} \mathrm{col}-$ umn of rock 200 meters long has a fracture volume of 2800 $\mathrm{cm}^{3}$. If we move $700 \times 30$ volumes of water through this rock, this would amount to $5.88 \times 10^{7} \mathrm{~cm}^{3}$ of water. Assuming this occurs over 100,000 years and a fracture area of about 14 per cent on the rock surface, each $\mathrm{cm}^{2}$ of open

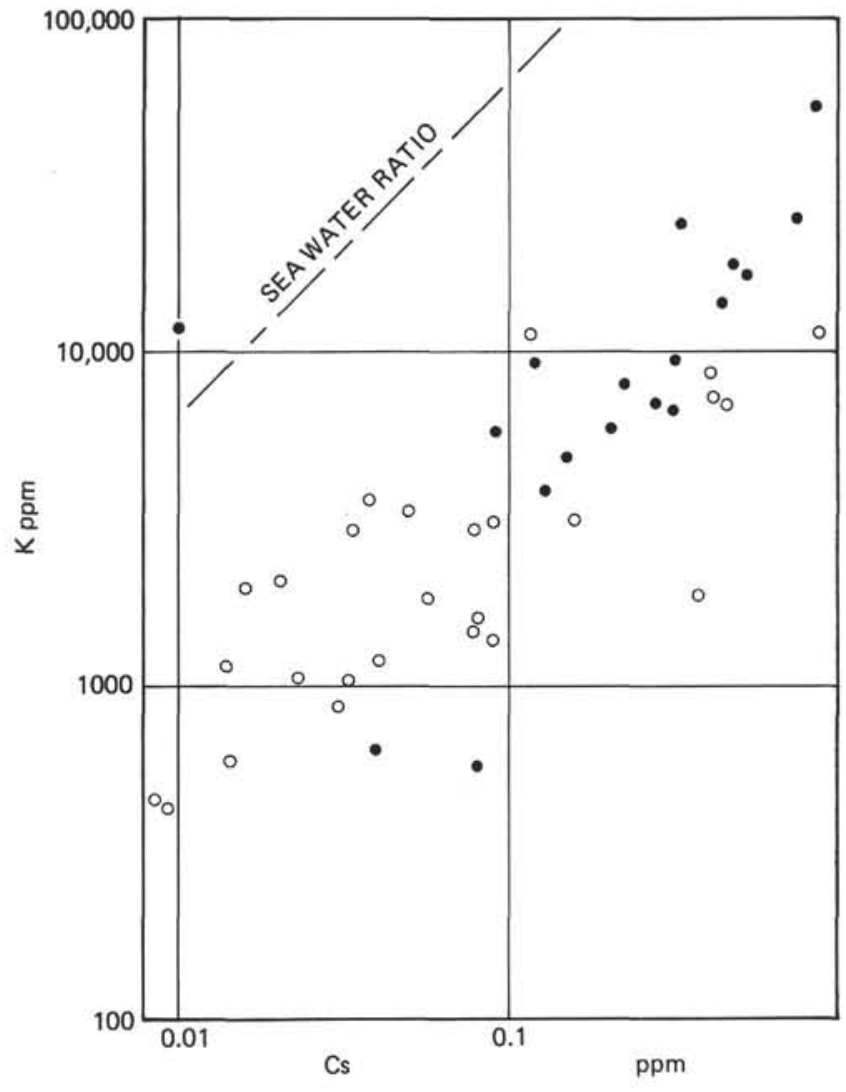

Figure 23. Diagram relating $\log K$ versus $\log C s$ for Sites 417 and 418. Symbols as in Figure 22. Dashed line represents the $K / C$ s ratio of sea water.

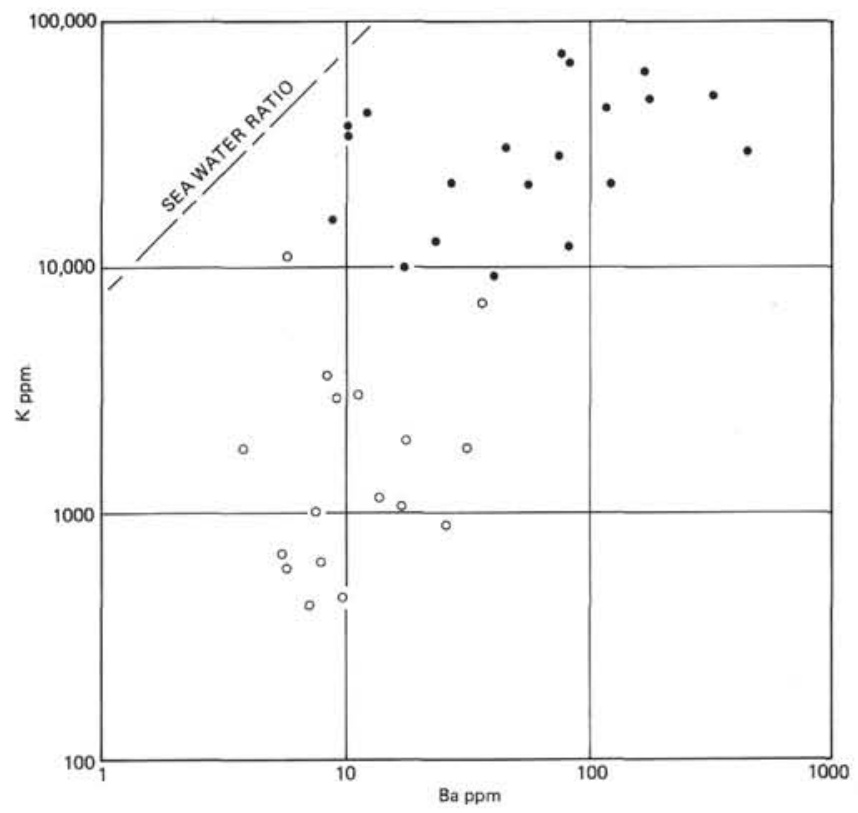

Figure 24. Diagram relating $\log K$ versus $\log B a$ for Sites 417 and 418. Symbols as in Figure 22. Dashed line represents the $K / B a$ ratio of sea water, assuming a $\mathrm{Ba}$ value of $0.05 \mathrm{ppm}$. 
fracture passes about $4200 \mathrm{~cm}^{3}$ per year, or somewhat more than $10 \mathrm{~cm}^{3}$ per day. Clearly such a flow velocity would be difficult to observe directly, especially if the temperature differential between the water circulating through the basement and sea water was very low. This implies that a process very much like the alteration process at Hole 417A could be occurring in the ocean floor today but would be very difficult to ascertain.

\section{SUMMARY: ALTERATION AND AGING OF THE CRUST}

Young crust may in places be altered as extensively as the crust in Hole 417A. The necessary requirement seems to be a situation in which huge quantities of water are made to move through the basement, probably driven by convective flow during crustal cooling. Topographically elevated areas would be favored, since they remain uncovered by sediment, and, hence, unplugged. Where crust is altered in this fashion, little can happen to it subsequently.

If young crust escapes this type of alteration, it is probably sealed off by accumulating sediments at a young age causing the water trapped in pores and veins to become stagnant. Its temperature might rise slightly because of the thermal blanketing effect of the sediment cover, but evidence shows that high temperatures (say $200^{\circ} \mathrm{C}$ ) are never reached. As the basalt remains in contact with trapped sea water it absorbs this water, releasing $\mathrm{Ca}$ and $\mathrm{CO}_{3}$ to the pores. Through deposition of new clay minerals and carbonate, the fractures tend to fill. Although the basalt can absorb a limited amount of $\mathrm{K}$ and other elements from the pore water and although it can be oxidized to a small degree, the chemistry and oxidation state of the basalt change very little. Thus, the relationships between $\mathrm{K}$ and oxidation on the one hand and the degree of hydration on the other, made familiar by studies of dredged basalts exposed to an unlimited amount of sea water, have no bearing on the crust as a whole.

Also of interest is the character of this older crust at the time of its eventual subduction (if that is to be its fate). Unless it is exposed anew when descending the other wall of the trench and is secondarily oxidized or enriched in $\mathrm{K}$, it will go to its subduction much like the crust in Hole 417D or Hole 418A. Its water content would be substantial: a column $1 \mathrm{~km}$ thick with a $1 \mathrm{~cm}^{2}$ cross section and a water content of 1.5 per cent, would contain about $4200 \mathrm{~cm}^{3}$ of water. The subduction of this crust at a velocity of $10 \mathrm{~cm} / \mathrm{y}$ would yield about $4 \times 10^{9} \mathrm{~g}$ of water per $\mathrm{km}$ of island arc per year. If this were used for melting, and the melt produced contained 10 per cent water, then this would produce $1.5 \mathrm{~km}^{3}$ of volcanic magma per million years. Sugimura and Uyeda (1973) estimate a volume of Quaternary volcanics in Japan of about $5000 \mathrm{~km}^{3}$, or roughly $5 \mathrm{~km}^{3}$ per kilometer of arc. Thus, the water content of the crust alone could satisfy a considerable fraction of that needed for subduction melting of the andesitic suite.

\section{REFERENCES}

Andrews, A. J., Barnett, R. L., MacClement, B. A. E., Fyfe, W. S., Morrison, G., MacRae, N. D., and Starkey, J., 1977. Zeolite facies metamorphism, geochemistry and some aspects of trace element redistribution in altered basalts of DSDP, Leg 37. In Aumento, F., Melson, W. G., et al., Initial Reports of the Deep Sea Drilling Project, V. 37: Washington (U.S. Government Printing Office), p. 795-810.

Aumento., F., Melson, W. G., et al., 1977. Initial Reports of the Deep Sea Drilling Project, v. 37: Washington (U.S. Government Printing Office).

Baragar, W. R. A., Plant, A. G., Pringle, G. J., and Schau, M., 1977. The petrology of alteration in three discrete flow units of Sites 332 and 335. In Aumento, F., Melson, G. G., et al., Initial Reports of the Deep Sea Drilling Project, v. 37: Washington (U.S. Government Printing Office), p. 811-820.

Bass, M. N., 1976. Secondary minerals in oceanic basalts, with special reference to Leg 34, Deep Sea Drilling Project. In Yeats, R. S., Hart, S. R., et al., Initial Reports of the Deep Sea Drilling Project, v. 34: Washington (U.S. Government Printing Office), p. 393-432.

Corliss, J. B., Dymond, J., Gordon, L. I., Edmond, J. J., von Herzen, R. P., Ballard, R. D., Green, K., Williams, D., Bainbridge, A., Crane, K., and van Andel, T. H., 1979. Submarine thermal springs on the Galapagos Rift. Science, v. 203, p. 1073-1083.

Donnelly, T. W. and Nalli, G., 1973. Mineralogy and chemistry of Caribbean sediments. In Edgar, N. T., Saunders, J. B., et al., Initial Reports of the Deep Sea Drilling Project, v. 15: Washington (U.S. Government Printing Office), p. 929-961.

Donnelly, T. W., in press. Secondarily modified sediments of the eastern Pacific major-element chemistry of Sites 420, 424, and 425, DSDP Leg 54. In Hekinian, R., Rosendahl, B., et al., Initial Reports of the Deep Sea Drilling Project, v. 54: Washington (U.S. Government Printing Office).

Humphris, S. and Thompson, G., 1978. Hydrothermal alteration of oceanic basalts by seawater. Geochim. Cosmochin. Acta, v. 42, p. 107-125.

Robinson, P. T., Flower, M. F. J., Schmincke, U., and Ohnmacht, W., 1977. Low-temperature alteration of oceanic basalts, DSDP Leg 37. In Aumento, F., Melson, W. G., et al., Initial Reports of the Deep Sea Drilling Project, v. 37: Washington (U.S. Government Printing Office), p. 775-794.

Scarfe, C. M. and Smith, D. W. G., 1977. Mineralogy and chemistry of secondary phases in some basaltic rocks from DSDP Leg 37. In Aumento, F., Melson, W. G., et al., Initial Reports of the Deep Sea Drilling Project, v. 37: Washington (U.S. Government Printing Office), p. 825-832.

Seyfried, W. E., Shanks, W. C., and Bischoff, J. L., 1976. Alteration and vein formation in Site 321 basalts. In Yeats, R. S., Hart, S. R., et al., Initial Reports of the Deep Sea Drilling Project, v. 34: Washington (U.S. Government Printing Office), p. 385-392.

Sugimura, A. and Uyeda, S., 1973. Island Arcs. Japan and its environs: Amsterdam (Elsevier).

Tomasson, J. and Kristmannsdottir, H., 1972. High temperature alteration minerals and thermal brines, Reykjanes, Iceland. Contrib. Mineral. Petrol., v. 36, p. 123-134. 